Maurizio Pugno ${ }^{(1)}$ and Paolo Verme ${ }^{(2)}$

(1) Department of Economics, University of Cassino

(2) The World Bank, and Department of Economics "S.Cognetti De Martis", University of Torino

\title{
Life Satisfaction, Social Capital and the Bonding-Bridging Nexus
}

December 2011 
Dipartimento di Scienze Economiche

Università degli Studi di Cassino

Via S.Angelo Località Folcara, Cassino (FR)

Tel.+3907762994734 Email dipse@eco.unicas.it 


\title{
Life Satisfaction, Social Capital and the Bonding-Bridging Nexus
}

\author{
Maurizio Pugno* and Paolo Verme ${ }^{\dagger}$ \\ September 2011
}

\begin{abstract}
The paper investigates the relation between social capital and life satisfaction focusing on the distinction between bonding and bridging as introduced by Putnam (2000). Using the latest version of the combined World and European Values Surveys, we first address the question of measurement of social capital by means of a multi-step factor analysis. Through this procedure, we find that proxies typically used for social capital tend to polarize around two dimensions interpreted as bonding and bridging. These two dimensions are in fact associated with a single latent variable with opposite signs suggesting that they describe two sides of the same latent variable rather than two independent latent variables. We call this latent variable the locus of socializing and use it to explore the relation between social capital and life satisfaction across world citizens and across groups of similar countries. The results indicate that people with extreme bonding or bridging behavior are less happy than people with more balanced attitudes. Unlike the literature on social capital and economic growth that finds bridging attitudes more desirable than bonding attitudes, we find that bonding attitudes are at least as important as bridging attitudes for life satisfaction. This suggests that the social capital dimensions important for economic growth may not necessarily coincide with the social capital dimensions important for life satisfaction.
\end{abstract}

JEL: A13, D6, I3, Z1.

Keywords: Life Satisfaction, Social Capital, Bonding, Bridging.

${ }^{*}$ Department of Economic Sciences, University of Cassino, Campus Folcara, via S.Angelo, 03043 Cassino (FR), Italy.

†The World Bank and Department of Economics "S. Cognetti de Martiis", University of Torino, Via Po 53, 10124, Torino, Italy. 


\section{Life Satisfaction, Social Capital and the Bonding-Bridging Nexus}

\section{Introduction}

Social capital is a relatively new concept in economics, but the literature on the subject is already rich and controversial. It has been recognized that this concept captures a phenomenon important for economics, in that it relates to trust and cooperation, and hence to efficiency and economic growth. At the same time, economists have brought several criticisms against the concept of social capital, such as its vague definition and the difficulty of its measurement (Durlauf and Fafchamps 2005; Dasgupta 2005; Paldam and Svendsen 2000).

The definition of social capital varies across the social sciences. In sociology and in political science, social capital is often defined as a concept pertaining to organizations, or even nations, because it has been mainly referred to social relationships and supporting structures (Putnam 2003; Fukuyama 1997). Economics, and in part Bourdieu (1986), have usually defined the concept of social capital, as it was originally conceived by Loury (1977), and then developed by Glaeser et al. (2003), as pertaining to individuals.

Social capital has also been criticized for the difficulty of its measurement. The concept emerges from the literature as multidimensional and as including immaterial components. Economists seemingly prefer to focus on some specific variables usually considered to be indicators of social capital, like trust (e.g. Glaeser 2000; Fehr 2009; Alesina and La Ferrara 2002), or membership of social organizations (Glaeser et al. 2000). Instead, when the concept of social capital has been explicitly treated, it is generally considered as a latent variable captured by various proxies (Beugelsdijk and Smulders 2009).

Recently, social capital has attracted growing interest, also among economists, in relation to individual self-reported life satisfaction. ${ }^{1}$ This relationship has been usually found to be positive, and in some cases very significant, depending on the indicators used for social capital (Bjornskov, 2006, Helliwell, 2006, 2008, Ram, 2010, Leung et al., 2011). However, the relationship between social capital and economic growth, which has been studied in the economic literature since the seminal article by Knack and Keefer (1997),

\footnotetext{
${ }^{1}$ For a discussion on the concept of self-reported life satisfaction see Layard (2005), Kahneman and Krueger (2006), and Veenhoven (2007).
} 
is not as consistent in predicting a positive role of social capital. For example, Olson's (1982) economic analysis of interest groups and Banfield's (1958) sociological analysis of "amoral familism" find a negative relationship between social capital and economic growth.

Putnam (2000) has in fact recognized that social capital may display positive or negative externalities and proposed the distinction between bonding and bridging social capital in order to study these divergent effects. Bonding social capital emerges when trust and cooperation are restricted within groups, so that negative externalities may ensue for other people. Bridging social capital emerges when new linkages between groups arise, so that cooperation increases. Recent exploratory findings in the economic literature seem to confirm that bonding and bridging social capital can be considered as two distinct variables, and that the former has a negative effect on economic growth and the latter has a positive effect (Knudsen et al. 2010; Beugelsdijk and Smulders 2009).

Moreover, some studies show that family ties, usually included in bonding social capital, causally reduce trust in people, which is the basic indicator for bridging social capital (Alesina and Giuliano 2009; Ermish and Gambetta 2008) while other studies show that both family ties and trust in people are positively correlated with people's life satisfaction (Alesina and Giuliano 2007, Helliwell and Wang 2010).

Two main problems thus clearly emerge. First, how to distinguish between the bonding and bridging dimensions starting from a variety of proxies for social capital, and how the bonding dimension is related to the bridging dimension. Second, how these two dimensions of social capital are related to individual life satisfaction: in particular, whether they relate positively in any case, thus departing from the mixed results on the relationships of bonding and bridging social capital with economic growth.

In addressing these two problems, and by using a large world dataset, this paper obtains two main surprising results. First, proxies for bonding and bridging social capital appear to describe two sides of the same latent variable, rather than two distinct latent variables. This would imply that bonding and bridging cannot be conceived as two distinct dimensions of social capital but should instead be seen as two opposite sides of a single dimension of social capital, which is a broader concept possibly including other dimensions. This result prompts us to call the bonding/bridging dimension the locus of socializing, in order to emphasize that it is where people mostly enjoy social relationships, whether within their kinship and existing ties, or across new social ties. 
The paper also reports a second surprising result: that often balanced attitudes towards bonding and bridging predict life satisfaction better than extreme bonding or bridging attitudes. For example, individuals who attach more importance to the family than to friends, or more importance to friends than to the family, appear to be less satisfied with their lives than individuals who take a more balanced view. The same applies for the importance of work with respect to leisure. Individuals who hold balanced views on the importance of work and leisure seem happier than individuals who have unbalanced preferences. Overall and with one exception, bonding variables tend to deliver more happiness than bridging variables, a finding consistent with previous literature on social capital and life satisfaction.

These results are obtained by carefully examining the available literature and the available proxies for bridging and bonding social capital in the latest version of the combined World and European Values Surveys (WVS-EVS) and by applying a multistep factor analysis for the identification of the bonding and bridging latent variables. This approach has induced us, in particular, to pay more attention than in the past to self-reported values and beliefs such as the importance attached to family, work and children's qualities. This is in line with the theoretical and empirical arguments on the role of culture in economics (Guiso et al. 2006, Tabellini, 2010).

The paper is organized as follows: section 2 conducts an in-depth review of the literature on bonding and bridging social capital in order to evidence the motivation of the paper; section 3 describes the data and the model used; section 4 analyses how bonding relates with bridging indicators; section 5 sets out the results on the relationship between the bonding/bridging dimension and individuals' life satisfaction; and section 6 concludes.

\section{Motivation and literature review}

The importance of social capital for economists is evident from the variety of economic phenomena that have received better explanation with the use of the concept of social capital, such as economic growth (Knack and Keefer 1997), and, among others, individual self-reported life satisfaction and happiness.

The literature on what is now called 'happiness economics' has been growing rapidly, often by basing the analysis on psychology, and by yielding implications for public policy. A variety of evidence on the validation and reliability of subjective data of this kind has 
also been provided, so that happiness economics can be regarded as both a field and a method of research (Stutzer and Frey 2002, 2010; Konow and Earley, 2008). One of the most robust findings in happiness economics is that marriage and social life play a key role in individuals' life satisfaction, and that it is not less important than household income (Layard 2005; Nickerson et al. 2003; Wilson and Oswald 2005).

More specific studies on the role of social capital in individuals' life satisfaction show a number of results:

- First, social capital, as captured by the three main indicators of trust, networks, and norms (Putnam, 1993:167), contributes greatly and significantly to explaining the cross-country variance of individual life satisfaction. Besides trust in people, typical proxies used for social capital in Putnam's sense are 'membership of social organizations', 'having someone to rely on', 'donating money or time to an organization', contacts with family, friends and neighbors, 'justifying cheating on taxes', 'importance of religion', 'religious practice', and other proxies for governmental quality (Helliwell 2008, 2006). Helliwell et al. (2009) even conclude that in all [world] regions [...] social support is tightly linked to life satisfaction, with a global coefficient that exceeds that on log income. ${ }^{2}$

- Second, time devoted to social relationships causally impacts on life satisfaction in a positive and relevant way (Meier and Stutzer 2008; Becchetti et al. 2008; Bruni and Stanca, 2008). Proxies for the time devoted to relations are 'frequency in performing volunteer work', 'attending social gatherings', 'cultural and religious events'.

- Third, the deterioration of social capital in the US over the most recent decades, as claimed by Putnam (2000) and confirmed by others (Costa and Kahn 2003; Robinson and Jackson 2001), is associated with the decline of individuals' happiness in the same country, as reported by Layard et al. (2009), Easterlin and Angelescu (2009), and Stevenson and Wolfers (2008). This linkage seems to be significant and relevant, even after controlling for individuals' income and comparison income (Bartolini et al. 2008; see also Bjørnskov 2008).

\footnotetext{
${ }^{2}$ Similar conclusions are found by Winkelman (2009), who has used panel data for Germany, and by Leung et al. (2011), who have used non-panel data for Canada, while Ram (2010) has found more fragile results by using country data instead of individual data.
} 
Social capital is a broad term and economists have typically criticized the concept for its vague definition and the difficulty of its measurement (Durlauf and Fafchamps, 2005; Dasgupta 2005; Paldam and Svendsen, 2000). Economics has thus preferred to focus on specific observable variables rather than latent variables (Glaeser, 2000, Fehr, 2009, Alesina and La Ferrara, 2002) and on individuals rather than societies at large (Loury, 1977; Glaeser et al., 2003).

The sociological literature recognizes the problem of the multidimensionality and ambiguity of social capital but proposes the distinction between bonding and bridging social capital. Putnam (2000:22-24), in particular, devotes some interesting theoretical considerations to this distinction: "Of all the dimensions along which forms of social capital vary, perhaps the most important is the distinction between bridging (or inclusive) and bonding (or exclusive). Some forms of social capital are, by choice or necessity, inward looking and tend to reinforce exclusive identities and homogeneous groups. [...] Other networks are outward looking and encompass people across diverse social cleavages. [...] Bonding social capital, by creating strong in-group loyalty, may also create strong out-group antagonism, [...] and for that reason we might expect negative external effects to be more common with this form of social capital. Nevertheless, under many circumstances both bridging and bonding social capital can have powerfully positive social effects."

This distinction has been taken up and discussed by other authors, so that two aspects clearly emerge (Gittel and Vidal 1998; Woolcock and Narayan 2000; Wallis et al. 2004). Whereas bonding social capital arises when individuals strengthen existing ties within a community, thus reinforcing trust for specific people and specific actions, bridging social capital arises when individuals explore new ties and links with other communities, thus facing a greater risk. Whereas bonding social capital may generate negative externalities among different communities due to the pursuit of sectarian interests, bridging social capital generates positive externalities among different communities, because of the creation and exploitation of new opportunities.

The reason for the interest in the distinction between bonding and bridging social capital regards the externalities effects, which make it possible to predict whether the effects of social capital are positive or negative. Distinguishing between bonding and bridging would also be instrumental in separating the definition of social capital from its effects. The negative effects of closed interest groups on the economy are well-known in 
both economics (Olson 1982) and sociology (Banfield 1958), so that one would expect to find a great deal of empirical research on the distinction between bonding and bridging social capital. Instead, there are few studies on this distinction, and they are especially rare in economics. Putnam (2000: 23) frankly admits that "I have found no reliable, comprehensive, nationwide measures of social capital [for the US] that neatly distinguish 'bridgingness' and 'bondingness'."

The few economic studies to have considered the bonding/bridging distinction in the analysis of the positive effects of social capital focus on economic growth. A much-cited study in this regard is Knack and Keefer (1997), which is based on the World Value Survey (WVS). Its main finding is that trust of the survey's respondents impacts positively and significantly on a country's economic growth. The subsequent literature has largely confirmed this result (e.g. Zak and Knack 2001; Beugelsdijk et al. 2004; Dearmon and Grier 2009). Knack and Keefer then attempt to apply the bonding/bridging distinction of social capital, though they do not use this terminology. In fact, they distinguish people's participation in social organizations depending on the kind of organization, i.e. whether it is of the Putnam variety, like cultural organizations which enhance cooperation and solidarity, or of the Olson variety, like political parties, which are rather motivated by rent-seeking behavior. However, although the estimated coefficients in the overall GDP growth equations differ between the two kinds of organization, they are not significant.

Two other very recent studies focus on regional growth in the US and the EU respectively. Knudsen et al. (2010) apply factor analysis to distinguish among the different kinds of participation in social organizations. However, they only find that participation is not of the same kind, so that they are obliged to fix an a priori criterion, and to plead for "experts" for its application. They can thus distinguish organizations into two groups depending on whether these organizations are exclusive or inclusive with respect to new entrants. The authors again apply factor analysis to several indicators of social capital, and find two substantial factors that can be attributed to bridging and bonding social capital respectively. The first factor has positive and substantial loadings on the indicators of 'diversity of friendships', 'inclusive organizations', and 'political activity', while the second factor has positive and substantial loadings on the indicators of 'exclusive organizations' and 'faith-based engagement'. The other loadings in both factors are instead negligible. After the application of other tests, it is finally concluded that 
bonding and bridging are two distinct dimensions.

When Knudsen et al. (2010) estimate growth equations based on the results of the factor analysis, an interesting result emerges: the bridging composite indicator is positively correlated with regional income growth, but the bonding composite indicator is negatively correlated. A similar result with composite indicators is obtained by Beugelsdijk and Smulders (2009). However, their distinction between bonding and bridging proxies is a priori, like that of Knack and Keefer. They select bridging social organizations on the basis of presumed non-rent-seeking activity, while the bonding composite indicator is built on the survey questions concerning the 'importance of family, friends and acquaintances'.

The result that the bridging and bonding types of social capital display a correlation with economic growth with opposite signs has been further confirmed for some specific indicators. For example, Tabellini (2010) selects four social capital indicators: generalised trust, 'feeling free and controlling over own life', and the importance attached to child's respect for other people, and obedience. A certain bridging/bonding distinction emerges from the principal component analysis, which shows that the first principal component of these four indicators displays a positive correlation with the first three, and a negative correlation with the obedience indicator. The estimate of growth rates in the EU regions again shows that the first three indicators display a positive sign, and the obedience indicator displays a negative sign.

Guiso et al. (2010) specifically address the civic component of social capital, which may be included in bridging social capital. The selected survey questions regard the justification for 'claiming government benefits when not entitled', for 'cheating on taxes', and for 'accepting a bribe in the course of own duties'. The authors find that these three indicators are positively correlated with their first principal component, but that the principal component is not significantly correlated with economic growth, although its correlation with some proxies for government efficiency is positive and significant.

A particular aspect of the distinction between bonding and bridging social capital that has been specifically investigated is the relationship between family ties and generalised trust. This relationship would be ambiguous on a priori grounds, because, on the one hand, children learn trust within the family as a necessary proving ground for extending trust to other people, as developmental psychologists argue (e.g. Ainsworth et al. 1978; Kafetsios and Nezlek 2002) while, on the other hand, family ties may limit 
opportunities and motivation for outward exposure, thus limiting trust in strangers (Ermish and Gambetta 2008). Family ties would thus display a positive relationship with generalized trust in the former case, and negative in the latter case.

The paper by Alesina and Giuliano (2009) shows that the relationship between family ties and generalised trust is negative when the strength of family ties is measured on reported scores for the 'importance of the family in an individual's life', the 'duties and responsibilities of parents and children' and the 'love and respect for ones parents'. This result is based on the WVS and has been confirmed by experimental data by Ermish and Gambetta (2008), who add that the negative causality runs from family ties to generalised trust.

Another aspect of the distinction between bonding and bridging social capital which has been investigated is the relationship between religiosity and generalised trust. Guiso et al. (2003), on the basis of the WVS, find positive and significant correlations between generalised trust and some measures of religiosity, i.e. 'raised religiously at home', 'attending religious services', and 'believing in God'. This result is confirmed by Helliwell (2008). However, religious denomination matters significantly (Glaeser et al. 2000; La Porta et al. 1997). For example, Guiso et al. (2010) show that the proportion of Catholics in the population is negatively related with trust in strangers. Regarding economic growth, Barro and McCleary (2003) show that this seems to respond positively to the extent of religious beliefs, but negatively to church attendance.

Generalised trust is clearly included in bridging social capital, but the survey question normally used to measure generalised trust in many studies has raised some problems in this regard. The question, which also appears in the WVS, is "Generally speaking, would you say that most people can be trusted or that you can't be too careful in dealing with people?" The answer could be either "Most people can be trusted" or "Can't be too careful". Gleaser et al. (2000) argue, on the basis of a mix of survey and experimental data, that the survey question about trust predicts trustworthiness and not trust. If this result were confirmed by the literature, this question would give ambiguous information about bridging social capital. However, Fehr (2008), who also uses experimental evidence, finds that the trust question captures a component of trust as a social preference, and not just as a belief about others' trustworthiness and as a risk preference.

As regards the impact of social capital on individuals' life satisfaction, there are 
no studies in the economic literature that are specifically focused on the distinction between bonding and bridging. Bartolini et al. (2008) consider, besides generalized trust, people's participation in social organizations, whether of the Olson or Putnam variety, thus following Knack and Keefer (1997). The impact on life satisfaction of the former type of organizations emerges as negative and of little significance, while the impact of the latter emerges as positive and highly significant.

Other studies focus on the impact of specific indicators of social capital on life satisfaction, but their findings are not necessarily in line with the results discussed above. Family ties are found to be positively, significantly, and sizeably correlated with life satisfaction (Alesina and Giuliano 2007), which is consistent with the recurrent result of the positive association between marriage and life satisfaction. However, this same result is not easily reconciled with the negative correlation found between family ties and generalized trust, which is positively associated with life satisfaction.

A similar but less clear issue emerges from religiosity. This variable appears to be positively correlated with life satisfaction in several studies (Dolan et al. 2008; Clark and Lelkes 2009), but it also depends on the indicators of religiosity used (Helliwell 2008), and (according to psychologists) on the indicators of self-reported well-being used (Lewis 2005). In particular, if the life satisfaction scale is of the 'Cantril ladder' type, as in the Gallup Poll dataset, then the importance of religion does not show a significant correlation with life satisfaction (Helliwell 2009).

The conclusions from this brief review of the literature (summarized in Table 1) are thus the following. First, social capital cannot be taken as a homogeneous concept. In fact, some exploratory and partial analyses show that social capital can be captured by specific measurable indicators, which fit nicely with the definitions of bonding and bridging as two dimensions of social capital, and which seem to relate negatively to each other in some important instances. Therefore, further analyses on the relevance of this distinction should especially investigate the relationship between these two dimensions of social capital. Second, the distinction between bonding and bridging indicators of social capital is important because of their distinct role in growth and life satisfaction. The literature on social capital and growth has shown that specific individual indicators or composite indicators often relate positively with economic growth if they are of the bridging type, but negatively if they are of the bonding type. Similar studies on the role of bonding and bridging indicators for life satisfaction are still scarce. 
In the sections that follow, we will use the latest version of the WVS-EVS to address the two questions stated earlier: the definition and relation between bonding and bridging indicators; and the relation between these indicators and life satisfaction in the context of world regions characterized by different histories, cultures and levels of development.

\section{[TABLE 1]}

\section{Data, model and variables}

The data we use include all rounds of the WVS-EVS carried out between 1980 and 2008 . The data set was created by combining the 1981-2004 World and European integrated data file (version 2006.04.23) and the last round of the World Value Survey following the instructions provided by the World Values Survey organization (www.worldvaluessurvey.org). The resulting dataset includes five rounds of the World Values Surveys and three rounds of the European Values Surveys for a total of 98 countries, 1639 regions, 24 recorded years and 355,298 observations. This is the largest dataset of its kind to date.

Our final objective is to assess the impact of bonding and bridging attitudes on life satisfaction worldwide. For this purpose we use what can be described as a standard model when working on happiness cross-country and longitudinally with the WVS-EVS. The model is as follows:

$$
H_{i}=\alpha+\beta B_{i}+\gamma X_{i}+\eta C_{c}+\delta Y_{t}+\mu_{i}
$$

where $H$ stands for happiness, $B$ is a vector of variables representing bonding and bridging attitudes, $X$ is a vector of control variables representing individual and household characteristics, $C$ is a vector of countries dummies, $Y$ is a vector of years dummies, $\alpha, \beta, \gamma, \eta, \delta$, are the parameters to be estimated and $\mu$ is the error term. The subscript $i$ stands for individuals and the subscripts $c$ and $t$ stand for countries and time (years) respectively. Therefore, in the most general model, we pool all available observations for all countries and years and estimate the happiness equations on individuals with countries and years fixed effects. The same equation is applied to the full set of countries available and to 16 separate groups of countries representing different geographical areas, recent histories, cultures and levels of economic development. All equations are estimated with robust standard errors (Huber-White estimator) and regional clusters 
(within countries regions) relaxing in this way the assumption that observations within regions are completely independent.

As a measure of happiness $(H)$ we use life satisfaction. The question asked is "All things considered, how satisfied are you with your life as a whole these days?" Answers are on a ten step scale where ' 1 ' is equal to 'Dissatisfied' and ' 10 ' is equal to 'Satisfied'. This is a standard question in happiness studies, and it is also a question widely tested across the social sciences in terms of reliability of answers. As our dependent variable is categorical and ordered, all equations are estimated with an ordered logit model.

Our key variables are proxies for bonding and bridging attitudes and behaviors $(B)$, which we consider as latent variables. This is a recurrent approach in happiness and values studies and also an obligatory choice with the dataset we use. As already discussed in the previous section, there is no recognized single measure of bonding and bridging attitudes and behaviors in the literature, and our dataset does not measure these variables directly. The next section will discuss in detail the procedure we followed to identify the proxies for our bonding and bridging latent variables.

We also use a set of controls in all equations $(X)$. These are age (simple and squared) and dummies for the following variables: female; low education and upper education ('middle education' is the base category); married ('married' and 'living together as married'); families with no children and families with three or more children (families with 1-2 children is the base category); subjective good health (respondents who replied that health was 'good' and 'very good') and subjective bad health (respondents who replied that health was 'poor' and 'very poor'. Subjective 'fair' health is the base category); breadwinner; part-time workers, self-employed workers, unemployed and inactive individuals (the base category is 'employed full-time'); low income people (first to third step in a ten step income scale) and high income people (eighth to tenth step in the ten step scale. The base category is middle income people - fourth to seventh step in the same scale). Therefore, when we assessed the role of bonding and bridging in a life satisfaction equation, we controlled for work status and income status in addition to the standard individual characteristics.

\section{The nexus between bonding and bridging}

We started from the assumption that it is possible to characterize bonding and bridging attitudes so as to form two groups of measures. The theoretical guiding distinction 
was that values and beliefs indicative of the strengthening of existing ties within a welldefined community are associated with bonding attitudes, whereas values and beliefs indicative of the exploration of new ties and links with strangers are associated with bridging attitudes.

In this section, we report an exploratory analysis conducted to test whether the theoretical distinction between the concepts of bonding and bridging holds with empirical data. More precisely, this exploratory analysis was expected to show: (i) whether the set of measures selected was able to predict two different latent variables, so that two separate groups of measures loaded positively on two different distinguishable factors; or alternatively (ii) whether the two groups of measures emerged as negatively correlated and loaded on the same factor, suggesting that these two groups of measures were in fact two sides of the same latent variable. In other words, we attempted formally to test Putnam's (2000:23) contention that 'bonding and bridging are not 'either-or' categories into which social networks can be neatly divided, but 'more or less' dimensions along which we can compare different forms of social capital."

To test this hypothesis, we followed a procedure articulated into the four steps now described.

Step 1. We were initially guided by theory, the existing literature, and the availability of variables with a sufficiently large number of observations (not all variables were available in all waves and for all countries in the WVS-EVS) to select a reduced set of proxies for bonding and bridging attitudes from the over 900 variables available in the database. In this way, we identified a first set of variables that are typically used in similar analyses to proxy bridging or bonding. These variables were grouped grouped into four areas: 1) the importance attributed by respondents to a set of items (family, friends, religion, politics, leisure and work); 2) the importance attributed to selected child qualities (independence, hard work, responsibility, imagination, tolerance and respect for other people, thrift for saving money and things, determination and perseverance, religious faith, unselfishness and obedience); 3) trust (trust in people and trust in a set of institutions including churches, armed forces, press, labour unions, police, parliament, civil service, television, government, political parties and major companies); and 4) whether respondents considered as justifiable a set of behaviors (receive social benefits, avoid public transport fees, cheat on taxes, accept bribes, homosexuality, prostitution, abortion, divorce, euthanasia and suicide). Compared to the literature reviewed, the 
only important area that was missing concerned membership in organizations. According to several authors, this is an important variable that reveals bonding or bridging behaviors. However, the use of this variable in the WVS would have reduced the usable sample by half and would have severely restricted our possibility to investigate bonding and bridging attitudes across groups of countries, which was a central concern of our analysis.

Step 2. In a second stage, we used factor analysis within each of the four groups of variables selected in order to try to reduce the number of variables and assess whether bonding and bridging variables best relate to two separate diemensions or to one dimension only. This allowed us to discard some of the variables with little loadings on the latent variables and also to exclude those variables that simply replicated each other. For example, it emerged rather clearly that attitudes towards homosexuality, prostitution, abortion, divorce, euthanasia and suicide captured the same types of individuals. As a consequence, we retained only one factor that provided a large loading and also a significant number of positive answers ('justified homosexuality'). It also emerged quite clearly that, within each group of variables, the variables selected polarized around two latent factors, which we hypothesized to be bonding and bridging attitudes. These variables were importance of family, importance of religion, importance of work, child obedience and trust in institutions for the latent variable we considered as 'bonding', and child independence, child imagination, justified homosexuality and trust people for the latent variable we considered as 'bridging'.

These results are largely in line with previous studies (see section two). ${ }^{3}$ One might consider trust in institution as a bridging rather than bonding variable but the factor analysis we conducted puts this variable together with the other variables that are typically associated with bonding. It could be argued that people who have greater trust in institutions such as the church or the armed forces are typically those people who also put greater emphasis on the institution of marriage and family. However, the point of Step 2 of the analysis was to be driven by the data rather than by ex-ante assumptions and the data suggests to treat trust in institution together with other variables typically associated with bonding.

Step 3. Next, we used again factor analysis to address the question of whether bonding and bridging attitudes could be considered as two separate variables or two

\footnotetext{
${ }^{3}$ Results for this stage of the analysis have been omitted but they are available on request.
} 
sides of the same variable. Are people less bonding also invariably more bridging (and vice-versa) or can people be more (or less) bonding and bridging at the same time? To address this question we carried out a factor analysis with the variables selected in Step 2. The results are shown in Table 2. It can be seen (top panel) that only the first factor has an Eigenvalue sufficiently high to be retained. ${ }^{4}$ In other words, the analysis suggested that our proxies for bonding and bridging attitudes were jointly related with only one latent variable in some meaningful way. It can also be seen (bottom panel) that the five variables that we considered as proxies for bonding attitudes all load positively against the first factor while the four variables that we considered as proxies of bridging attitude all load negatively against the same factor. ${ }^{5}$ This finding suggests that the two sets of variables that we identified could in fact represent two sides of the same latent variable. This is a new result in contrast with those in the existing literature. For example, Knudsen et al. (2010) find, on the basis of US data, that two factors should be retained, and that the proxies for bonding and bridging attitudes correspondingly load on the two factors, thus concluding that bonding and bridging are two separate latent variables (see section 2).

\section{[TABLE 2]}

Step 4. As a further test for the preliminary finding of step 3, we carried out a third factor analysis exercise (Table 3). This time we assumed that bonding and bridging attitudes were two sides of the same variable and we constructed proxies for a single latent variable by building variables with low scores corresponding to bonding attitudes and high scores corresponding to bridging attitudes. We constructed five of these variables using some of the same variables we used in step 3 as well as some of the variables discarded in step 2 but useful for this last exercise. The first variable (importance of family vs. importance of friends) was constructed by attributing a value of ' 1 ' to those people who equally valued family and friends, a value of ' 2 ' to those people who valued family more than friends and a value of ' 3 ' to those people who valued friends more than family. We used the same construction procedure for the variables 'importance of work

\footnotetext{
${ }^{4}$ Different authors tend to use different cut points to decide how many latent factors should be retained. Here we use a cut point of 0.7 , which is a rather standard choice, and also look at the distance between factor loadings.

${ }^{5}$ Note that in table 2 and 3 we report results for the first four factors, even if we retain only the first factor. This is to show how none of the other factors provides a clear interpretation relatively to the variables selected in Step 2.
} 
vs. importance of leisure' and 'importance of religion vs. importance of politics'. In this way, we could use in the factor analysis the value of ' 1 ' as a base category and we were able to distinguish well between bonding and bridging extremes. One other variable was constructed by attributing a value of ' 1 ' to those people who valued child independence but did not value child obedience. A last variable was constructed giving a value of ' 1 ' to those individuals who have great trust in people but not in institutions. In the same factor analysis, we also added the variable 'justified homosexuality'. We expected people more tolerant of homosexuality to be more bridging and less bonding. In short, all variables were constructed with low values representing 'bonding' and high values representing 'bridging'. More details on the construction of the variables are given in Table 1 in the Annex.

The results in Table 3 (top panel) show again that only the first factor could be safely retained in the analysis and that the variables constructed are all related to only one latent variable. The table also shows (bottom panel) that all six variables constructed are positively associated with the latent factor. Indeed, low values (bonding) of the constructed variables show negative loadings, and high values (bridging) show positive loadings with respect to the middle values, which represent equal weights attributed to bonding and bridging attitudes. We can also see that the highest loadings are associated with the variables 'religion vs. politics', 'work vs. leisure' and 'justified homosexuality'. It follows that the concepts of bonding and bridging can be considered as two sides of the same concept, and that treating these two concepts as one may be useful in empirical applications.

These results would suggest coining a new expression for the bonding/bridging dimension of social capital. We propose the term locus of socializing ${ }^{6}$, which would stress two important aspects: 1) that social capital is a broader concept that includes other

\footnotetext{
${ }^{6}$ Locus of socializing recalls a term used in social psychology, namely the locus of control. The locus of control indicates the locus (place) where people think their decisional sphere is situated. People who believe that everything that happens to them is due to faith or destiny are called 'externals', and those who think that everything that happens to them is due to their own behavior are called 'internals'. Social psychology posits that the locus of control can be measured on one monotonic and increasing scale where the 'internals are on the right hand side of the scale and the "externals are on the left-hand side. Similarly, we posit that the locus of socializing is the locus where people invest most of their socializing time. Bonding types tend to devote most of their time to relations with family, church, work and close kin, while bridging types tend to devote relatively more time to relations outside their close kin. See Rotter (1966) for the concept of the locus of control and Verme (2009) for an analysis of the locus of control in the context of happiness and freedom.
} 
dimensions besides bonding and bridging ${ }^{7}$, and 2) that people face a trade-off in enjoying social relationships, either within their kinship and existing ties, or across new social ties.

[TABLE 3]

\section{Bridging, bonding and life satisfaction}

In this section, we turn to the life satisfaction equations which we use to try determining how bonding and bridging attitudes relate to happiness. We first use the pooled world sample with the disaggregated proxies for bonding and bridging attitudes, assuming these variables as two separate concepts (Table 4). We then use the constructed proxies of the locus of socializing. We assume bonding and bridging attitudes as two sides of the same variable and test these proxies on the world sample and across groups of similar countries (Tables 5, summarized in Table 6). ${ }^{8}$

Table 4 shows that all bonding indicators are positively and significantly correlated with life satisfaction, and with a sizeable coefficient as compared to the standard controls. The most important indicators are 'importance of family', 'importance of religion', and 'trust in institutions'. But also 'importance of work' and 'child obedience' are positively and significantly correlated with life satisfaction. The positive correlations of the bonding indicators used with life satisfaction are not new results with respect to those in the literature (see section 2). However, our previous analysis and the estimations in Table 4 show in more detail how different and interlinked components of bonding can affect life satisfaction.

The results for the bridging indicators are more mixed. We find 'trust in people' to be positive and significant, 'homosexuality is justifiable' negative and significant, while 'child independence' and 'child imagination' are non-significant. Whereas the finding on trust is not new, the finding on tolerance of homosexuality is rather surprising. The proportion of homosexuals in the population has been used in some studies as a proxy for bridging attitudes in the composite 'creativity index', which, in its turn, has been

\footnotetext{
${ }^{7}$ For example, Woolcock (2001) considers 'linking social capital', besides bonding and bridging social capital.

${ }^{8}$ The choice of world regions rather than single countries is dictated by the number of observations available given the type of equation. Table 2 in annex provides the full list of countries and number of observations for each world region.
} 
found to be a good predictor of economic growth (Florida 2002). In our estimations, people who report that 'homosexuality is justifiable' do not appear to be relatively more satisfied, which suggests that there may be a trade-off between the objectives of life satisfaction and growth. The negative relation between 'homosexuality is justifiable' and life satisfaction is also quite consistent across the world regions. The regional equations (Table 5, summarized in Table 6) show that this variable carries a negative and significant coefficient in 10 of the 16 equations, while in five equations the variable is non-significant. Only in one region of the world (CIS countries) does 'homosexuality is justifiable' carry a positive and (weakly) significant sign. CIS countries include the former Soviet Union countries with the exception of the Baltic countries. We know that attitudes towards homosexuality in these countries are very conservative, and the explanation of this sign may be that people who are more open towards homosexuality are in fact a restricted and self-selected group of happier people.

\section{[TABLE 4]}

Table 5 reports the results for the world and for groups of similar countries using the composite indicators of what we called the locus of socializing. Our purpose here is to understand whether people who are more bonding or more bridging are comparatively happier. The composite indicator 'importance of family vs. importance of friends' shows a negative and significant coefficient for both high and low values, as compared to the middle level, where the importance of family is equal to the importance of friends. This means that individuals who attach a great deal of importance or little importance to the family with respect to friends also report a lower satisfaction than those who maintain a more balanced view. ${ }^{9}$ The coefficient of 'importance of family vs. importance of friends' exhibits the same pattern in the great majority of the 16 regions considered in Table 5, while it is non-significant in the remaining regions (see Table 6). Given the cultural and historical diversities of these groups of countries, our results seem rather strong. People with a more balanced view between bonding and bridging attitudes tend to be happier than people polarized around the extremes of the locus of socializing. ${ }^{10}$

\footnotetext{
${ }^{9}$ Note that people who give an equal weight to family and friends - the base category - could show different degrees of satisfaction. However, the point here is to see whether those who give different weights to family and friends exhibit opposite coefficients in relation to life satisfaction. If, on average, the happiest (or least happy) category was made of people who give equal weight to family and friends, then the other two categories would show the same sign, which is not the case.

${ }^{10}$ This finding is consistent with the research in developmental psychology showing that both hyper-
} 
Some studies have found that the 'importance of family' indicator may be detrimental to economic growth, possibly through the negative effects on trust in people (see section 2 ). Joining this result with our result would suggest that too much emphasis on the family may be detrimental to both individuals in their life satisfaction and their trust in people.

The composite indicator 'importance of work vs. importance of leisure' exhibits a similar pattern to that of 'importance of family vs. importance of friends'. The coefficients of this variable are negative for both people who attribute a great deal of importance to work relatively to leisure and, vice-versa, for people who attribute a great deal of importance to leisure and little to work. The regional equations summarized in Table 6 confirm the pattern of the two negative coefficients for all regions, although the coefficients are significant in only 8 of the regions for the bonding 'types' and in 6 of the 16 regions for the bridging 'types'. This result is consistent with the argument that too much emphasis on work, to the point of workaholism, may undermine individual health (Hamermesh and Slemrod 2008). It is also consistent with the finding that uninteresting jobs seem to lead to less satisfaction on the job (Helliwell and Huang 2005; Clark 2005). People with balanced views between work and leisure seem happier overall.

The composite indicator 'importance of religion vs. importance of politics' exhibits a different pattern. People who attach a great deal of importance to religion as compared to people with a more balanced view between religion and politics are happier (Table 5). This is confirmed by the fact that the same result persists in 10 of the 16 regions of the world, whereas in the remaining six regions (mostly former socialist or African countries) the coefficient is non-significant. Instead, people who express a preference for politics as compared to people with a balanced view between religion and politics do not seem to display any particular pattern. In two of the regions, the sign of the coefficient is positive and significant; in two regions it is negative and significant; and in the rest of the regions the coefficient is non-significant. The finding about religion is very consistent with the literature on happiness and religion (see section 2) while the finding on people with a preference for politics cannot be clearly interpreted. Perhaps the low number of people in this category explains the difficulty of finding a consistent and significant sign.

The coefficient for the variable 'child independence vs. child obedience' is negative

protective and dismissing parental child-rearing and education is detrimental to the healthy development of the child and to children's abilities in social relationships (Ainsworth et al. 1978; Kafetsios and Nezlek 2002). 
and significant for the pooled world sample. This is confirmed by the regional equations, where the coefficient of this variable is negative and significant in over half of the regions and non-significant in the remaining half. Attaching more importance to child independence than to child obedience predicts less life satisfaction. Interestingly, Tabellini (2010) has found that attaching more importance to child obedience predicts less economic growth. These two findings together are again indicative of a trade-off between the objective of increasing happiness and the objective of boosting economic growth.

A further new finding of Tables 5 and 6 regards the positive and significant coefficient of the variable 'trust in people vs. trust in institutions'. This result is consistent across the regions of the world, with the coefficient being significant in 7 of the 16 regions and non-significant in the remaining 9 regions. Regions where the coefficient is positive and significant are mainly the former socialist countries of Europe, where we know that trust in institutions used to be at very low levels, especially during the early years of the transition process (which is captured by our data). In substance, individuals with relatively more trust in people than in institutions are happier than those with a more balanced view. But this is the case only in those countries where trust in institutions was very low. Indeed, when the two variables trust in people and trust in institutions are treated separately (Table 4), they both carry a significant and positive sign and also show similar sizes in coefficients and standard errors.

[TABLES 5 and 6]

\section{Conclusions}

The paper has reconsidered the concepts of bonding and bridging introduced by Putnam (2000) in order to gain a better understanding of their nature and their association with life satisfaction.

An in-depth review of the literature has shown how the concepts of bonding and bridging are considered to be latent variables: they are not directly measured, and they have been empirically studied using a large number of proxies such as trust, attitudes towards social relations, various beliefs and behaviors. In all cases, the proxies for bonding and bridging have been distinguished a priori rather than on the basis of evidence so as to describe two separate aspects of the multidimensional concept of social capital. 
In this paper, we have endeavored to restrict the number of variables that could well depict bonding and bridging attitudes by means of a factor analysis conducted in four steps. As a result of this analysis, we have found that bonding and bridging attitudes are better described as two sides of the same latent variable, rather than as two different latent variables. We have called this new latent variable the locus of socializing to distinguish it from the broader concept of social capital. In fact, we have argued that the locus of socializing can be seen as a specific dimension of social capital and that different individuals or population groups can be more bonding or more bridging when they socialize.

Based on these findings, we have then studied the association between bonding and bridging and the locus of socializing with individual life satisfaction. We find that happier people are those who tend to have more balanced attitudes towards family and friends and towards work and leisure, compared with those who focus on only one type of socializing (bonding or bridging). We also find that more religious people are invariably happier than people more dedicated to politics; that people with a greater appreciation of child obedience are happier than people with a greater appreciation of child independence; and that people who do not justify homosexuality are happier. These are all indications that bonding attitudes may deliver more happiness than bridging attitudes. Instead, more trust in people, as opposed to more trust in institutions, yields more happiness, at least in some world regions. This we have interpreted as a sign that more bridging attitudes may deliver more happiness.

If we compare our results with those on social capital and economic growth reviewed in section 2 of this paper, we find that the recipe for happiness does not necessarily coincide with the recipe for economic growth. In particular, while bridging attitudes seem more beneficial for economic growth than bonding attitudes, a more balanced approach towards bonding and bridging may be conducive to more life satisfaction and, in some cases, bonding may deliver more happiness than bridging. Our findings are very preliminary, but they are likely to be crucial for better understanding of such longstanding issues as the "Easterlin paradox", i.e. the argument that economic growth is not necessarily associated with growth in happiness.

\section{References}

Ainsworth, M.D.S., Blehar, M.C., Waters, E., Wall, S. (1978) Patterns of Attachments: a Psychological Study of the Strange Situation. Hillsdale (NJ): Erlbaum 
Alesina, A., Giuliano, P. (2007) The power of the family, IZA DP, No. 2750

Alesina, A., Giuliano, P. (2009) Family ties and political participation, Harvard Institute of Economic Research. Discussion Paper No. 2171

Alesina, A., La Ferrara, E. (2002) Who trusts others?, Journal of Public Economics $85(2), 207-234$

Banfield, C.B. (1958) Moral basis of a backward society. New York : Free Press

Barro, R.J., McCleary, R.M. (2003) Religion and economic growth, American Sociological Review 68(5), 760-781

Bartolini, S., Bilancini, E., Pugno, M. (2008). Did the decline in social capital depress Americans' happiness?. Quaderni del Dipartimento di Economia Politica, n.540, University of Siena.

Becchetti, L., Pelloni A., Rossetti, F. (2008) Relational goods, sociability, and happiness, Kyklos 61(3), 343363

Beugelsdijk, S., Smulders, S. (2009) Bonding and bridging social capital and economic growth. Discussion Paper No.27, University of Tilburg

Beugelsdijk, S., de Groot, H.L.F., van Schaik, A.B.T.M. (2004) Trust and economic growth: a robustness analysis, Oxford Economic Papers 56(1), 118-134.

Bjornskov, C. (2008) Social capital and happiness in the United States. Applied Research Quality Life 3, 43-62

Bjornskov, C. (2006) The multiple facets of social capital. European Journal of Political Economy, 22, 22-40

Bourdieu, P. (1986) The forms of capital. In: John G. Richardson (ed.): Handbook of Theory and Research for the Sociology of Education. New York: Greenwood Press, 241-258.

Bruni, L., Stanca, L. (2008) Watching alone, Journal of Economic Behavior and Organization 65(3-4), 506-528

Clark, A. (2005) What makes a good job? Evidence from OECD countries. In Bazen, S., Lucifora, C., Salverda W. (Eds.), Job quality and Employer Behaviour, New York: Palgrave McMillan

Clark, A., Lelkes, O. (2009) Let us pray: religious interactions in life satisfaction, Working paper no. 2009/1, Paris School of Economics

Costa, D.L., Kahn, M.E. (2003) Understanding the decline in social capital, 19521998. Kyklos 56:17.46. 
Dasgupta, P. (2005) Economics of social capital, The Economic Record 81(255), 2-21

Dearmon, J., Grier, K. (2009) Trust and development, Journal of Economic Behavior and Organization 71(2), 210-220

Dolan, P., Peasgood, T. and White M. (2008) Do we really know what makes us happy? A review of the economic literature on the factors associated with subjective well-being. Journal of Economic Psychology, 29, 94-122

Durlauf, S.N., Fafchamps, N. (2005) Social capital. In:Aghion, A., Durlauf, S.N. (Eds) Handbook of Economic Growth. Amsterdam: North-Holland, 1639-99

Easterlin, R.A., Angelescu, L. (2009). Happiness and growth the world over: time series evidence on the happiness-income paradox. IZA Discussion Paper No. 4060, March.

Ermish, J., Gambetta, D. (2008) Do strong family ties inhibit trust?, Working Paper, no.37, Institute for Social and Economic Research, Nov.

Fehr, E. (2008) On the economics and biology of trust. IZA Discussion Paper no.3895

Fukuyama, F. (1997) Social capital and the modern capitalist economy, Stern Business Magazine 4(1)

Gittell, R., A. Vidal (1998) Community Organizing: Building Social Capital as a Development Strategy. Thousand Oaks, CA: Sage Books

Glaeser, E.L., Laibson, D., Sacerdote, B. (2002) An economic approach to social capital. Economic Journal 112, F437-58

Glaeser, E.L., Laibson, D., Sacerdote, B., Soutter, C. (2000), Measuring Trust, Quarterly Journal of Economics 115(3), 811-46

Guiso, L., Sapienza, P., Zingales, L. (2003) Peoples opium? Religion and economic attitudes, Journal of Monetary Economics 50, 225282

Guiso, L., Sapienza, P., Zingales, L. (2006) Does culture affect economic outcomes?, Journal of Economic Perspectives 20(2), 23-48

Guiso, L., Sapienza, P., Zingales, L. (2010) Civic capital as the missing link, Prepared for the Social Economics Handbook, edited by J. Benhabib, A.Bisin, M.O. Jackson

Hamermesh, D.S., Slemrod, J.B. (2008) The economics of workaholism, The B.E. Journal of Economic Analysis and Policy 8(1) (Contributions), Article 3

Helliwell, J.F. (2008) Life satisfaction and quality of development, NBER Working Paper No.14507.

Helliwell, J.F. (2006) Well-being, social capital and public policy: what's new? Eco- 
nomic Journal 116, C34-45

Helliwell, J.F., Putnam R. (1995) Economic growth and social capital in Italy, Eastern Economic Journal 21, 295-307.

Helliwell, J.F., F., Barrington-Leigh, C.P., Harris, A., Huang, H. (2009). International evidence on the social context of well-being, NBER Working Paper No.14720.

Helliwell J.F., Wang, S. (2010) Trust and well-being, NBER working paper, No. 15911

Kafetsios, K., Nezlek, J.B. (2002) Attachment styles in everyday social interaction, European Journal of Social Psychology 32(5), 719-35

Kahneman, D., Krueger, A.B. (2006) Developments in the measurement of subjective well-being, Journal of Economic Perspectives 20(1), 3-24

Knack, S., Keefer, P. (1997) Does social capital have an economic pay-off?. Quarterly Journal of Economics 112(4), 1251-88

Knudsen, B., Florida, R., Rousseau, D. (2010) Bridging and bonding: a multidimensional approach to regional social capital, University of Toronto (mimeo) available at: http://www.creativeclass.com

Konow, J., Earley, J. (2008) The hedonistic paradox, Journal of Public Economics 92(1-2), 1-33

Larsen, L., Harlan, S.L., Bolin, B., Hackett, E.J., Hope, D., Kirby, A., Nelson, A., Rex, T.R., Wolf, S. (2004) Bonding and bridging. Understanding the relationship between social capital and civic action, Journal of Planning Education and Research, $24,64-77$

Layard, R. (2005). Happiness: Lessons from a New Science. New York: Penguin Press

Layard, R., Mayraz, G., Nickell, S. (2009). Does relative income matter? Are the critics right?. CEP Discussion Paper No. 918, March (in Diener, E., Helliwell, J.F., Kahneman, K. (Eds) International Differences in Well-Being, New York: Oxford University Press, forthcoming)

Leung, A., Kier, C., Fung, T., Fung, L. and R. Sproule (2011), Searching for happiness: the importance of social capital, Journal of Happiness Studies, 12(3), 443-462

Loury, G. C. (1977) A dynamic theory of racial income differences. In: Wallace, P., LaMont, A. (Eds) Women, Minorities and Employment Discrimination, Lexington: Lexington Books. 
Meier, S. and Stutzer A. (2008) Is volunteering rewarding in itself?, Economica 75(297), 39-59

Nickerson, C., Schwartz, N., Diener, E., Kahneman, D. (2003) Zeroing in on the dark side of the American dream. Psychological Science 14(6), 531-6.

Olson, M, (1982) The rise and decline of nations. New Haven, CT : Yale University Press

Paldam, M., Svendsen, G.T. (2000) An essay on social capital. European Journal of Political Economy 16:339-66

Putnam, R.D. (1993) Making Democracy Work. Princeton NJ: Princeton University Press

Putnam, R.D. (1995) Bowling Alone, Journal of Democracy, 6(1),65-78

Putnam, R.D. (2000) Bowling Alone. New York: Simon and Schuster

Ram R (2010) Social capital and happiness, Journal of Happiness Studies, 11(4), $409-418$

Robinson. R.V., Jackson, E.F. (2001) Is trust in others declining in America? Social Science Research 30:117-45

Rotter, J. B. (1966). Generalised expectancies of internal versus external control of reinforcements. Psychological monographs 80 (609)

Stevenson, B., Wolfers, J. (2008). Economic growth and happiness. Brookings Papers on Economic Activity, May

Tabellini, G. (2010) Culture and institutions: economic development in the regions of Europe, Journal of the European Economic Association, 8(4), 677-716

Veenhoven, R. (2007) Subjective measures of well-being, in: McGillivray, M. (Ed.) Human Well-being: Concept and Measurement, Palgrave /McMillan, Houndmills, New Hampshire, USA, 214-239

Verme, P. (2009) Happiness, Freedom and Control. Journal of Economic Behavior and Organization. Vol. 71, Issue 2, August 2009, pages 146-161.

Wallis, J., Killerby, P. Dollery, B. (2004) Social economics and social capital, International Journal of Social Economics 31(3), 239-258

Woolcock, M. (2001) The place of social capital in understanding social and economic outcomes. In J.F. Helliwell (ed.), The Contribution of Human and Social Capital to Sustained Economic Growth and Well-being: International Symposium Report, Human Resources Development Canada and OECD. 
Woolcock, M., Narayan, D. (2000) Social capital: Implications for development theory, research, and policy, World Bank Research Observer 15(2), 223-49

Wilson, C.M., Oswald, A.J. (2005) How does marriage affect physical and psychological health?, IZA DP No. 1619

Ram R (2010) Social capital and happiness, Journal of Happiness Studies, 11(4), $409-418$

Winkelmann R (2009) Unemployment, social capital, and subjective well-being, Journal of Happiness Studies, 10(4), 421-430

Zak, P.J., Knack, S. (2001) Trust and Growth. Economic Journal 111:295-331. 
Table 1: Summary Table of the Literature on Bonding and Bridging Social Capital

\begin{tabular}{|c|c|c|}
\hline Study & $\begin{array}{c}\text { Indicators of social capital } \\
\text { (Indicators are identified as bonding or bridging only when they are labelled as such in the } \\
\text { original articles, when they are clearly defined in theory, or when they are thus found in the } \\
\text { present article.) }\end{array}$ & Outcomes \\
\hline Helliwell and Putnam (1995) & $\begin{array}{l}\text { - composite measure of: availability of sports and cultural associations; newspaper } \\
\text { readership; turnout in referenda; incidence of preference voting } \\
\text { - composite measure of institutional performance } \\
\text { - citizen satisfaction with government }\end{array}$ & $\begin{array}{l}\text { Positive associations with regional per } \\
\text { capita output growth in Italy }\end{array}$ \\
\hline \multirow[t]{2}{*}{ Knack \& Keefer (1997) } & $\begin{array}{l}\text { - trust in people } \\
\text { - sum of the scores from questions on justifiability of: } \\
\text { cheating on taxes; avoiding a fare; claiming government benefits; keeping found money; } \\
\text { failing to report damage to a parked vehicle }\end{array}$ & $\begin{array}{l}\text { Positive association with cross- } \\
\text { national per capita output growth }\end{array}$ \\
\hline & $\begin{array}{l}\text { - Olsonian group membership } \\
\text { - Putnamian group membership }\end{array}$ & $\begin{array}{l}\text { Non significant association with cross- } \\
\text { national per capita output growth }\end{array}$ \\
\hline \multirow[b]{2}{*}{ Barro and McCleary (2003) } & - religious beliefs & $\begin{array}{l}\text { Positive association with cross- } \\
\text { national per capita output growth }\end{array}$ \\
\hline & - church attendance & $\begin{array}{l}\text { Negative association with cross- } \\
\text { national per capita output growth }\end{array}$ \\
\hline \multirow[t]{2}{*}{ Knudsen et al. (2010) } & - factor analysis identifies exclusive groups, faith-based engagement & $\begin{array}{l}\text { Negative association with cross- } \\
\text { regional per capita income growth in } \\
\text { the US }\end{array}$ \\
\hline & - factor analysis identifies diversity of friendships, political activity, inclusive groups & $\begin{array}{l}\text { Positive association with cross- } \\
\text { regional per capita income growth in } \\
\text { the US }\end{array}$ \\
\hline \multirow[t]{2}{*}{$\begin{array}{l}\text { Beugelsdijk \& Smulders } \\
\qquad(2009)\end{array}$} & $\begin{array}{l}\text { - factor analysis identifies a one-dimension measure of the importance of family, friends } \\
\text { and acquaintances }\end{array}$ & $\begin{array}{l}\text { Negative association with cross- } \\
\text { regional per capita income growth in } \\
\text { Europe }\end{array}$ \\
\hline & - membership of selected non-rent-seeking groups & $\begin{array}{l}\text { Positive association with cross- } \\
\text { regional per capita income growth in } \\
\text { Europe }\end{array}$ \\
\hline $\begin{array}{l}\text { Guiso et al. } \\
(2010)\end{array}$ & $\begin{array}{l}\text { - the first principal component positively correlates with claiming government benefits when } \\
\text { not entitled, cheating on taxes, accepting a bribe in the course of own duties }\end{array}$ & $\begin{array}{l}\text { Non-significant association with cross- } \\
\text { national per capita output growth }\end{array}$ \\
\hline \multirow[t]{2}{*}{ Tabellini (2008) } & $\begin{array}{l}\text { - importance placed on child's obedience } \\
\text { (also identified in the first principal component) }\end{array}$ & $\begin{array}{l}\text { Negative association with cross- } \\
\text { regional per capita output growth in } \\
\text { Europe }\end{array}$ \\
\hline & $\begin{array}{l}\text { - trust in people } \\
\text { - importance placed on child's respect for other people } \\
\text { - people's freedom and control over their lives } \\
\text { (also identified in the first principal component) }\end{array}$ & $\begin{array}{l}\text { Positive associations with cross- } \\
\text { regional per capita output growth in } \\
\text { Europe }\end{array}$ \\
\hline \multirow{2}{*}{$\begin{array}{l}\text { Alesina \& Giuliano }(2009 \text {, } \\
\text { 2007) }\end{array}$} & \multirow{2}{*}{$\begin{array}{l}\text { - the first principal component of family importance, duty to love parents, parents' } \\
\text { altruism }\end{array}$} & $\begin{array}{c}\text { Negative association with trust in } \\
\text { people and with political participation }\end{array}$ \\
\hline & & $\begin{array}{l}\text { Positive association with individuals' } \\
\text { life satisfaction }\end{array}$ \\
\hline \multirow{2}{*}{$\begin{array}{l}\text { Helliwell et al. (2009), } \\
\text { Helliwell }(2008,2006)\end{array}$} & $\begin{array}{l}\text { - importance of religion } \\
\text { - having someone to rely on } \\
\text { - attending church }\end{array}$ & \multirow{2}{*}{$\begin{array}{l}\text { Positive association with cross- } \\
\text { national individuals' life satisfaction }\end{array}$} \\
\hline & $\begin{array}{l}\text { - proxies for governmental quality } \\
\text { - donated money to an organisation } \\
\text { - donated time to an organisation } \\
\text { - helped a stranger } \\
\text { - trust in people } \\
\text { - trust in police } \\
\text { - group membership }\end{array}$ & \\
\hline \multirow{3}{*}{ Bartolini et al. (2008) } & $\begin{array}{l}\text { - trust in institutions } \\
\text { - contacts with relatives }\end{array}$ & \multirow{2}{*}{$\begin{array}{l}\text { Positive association with individuals' } \\
\text { happiness over time in the US }\end{array}$} \\
\hline & $\begin{array}{l}\text { - trust in people } \\
\text { - contacts with neighbours and friends } \\
\text { - Putnamian group membership }\end{array}$ & \\
\hline & - Olsonian group membership & $\begin{array}{c}\text { Negative association with individuals' } \\
\text { happiness over time in the US }\end{array}$ \\
\hline Meier and Stutzer (2008) & - frequency in volunteer work & $\begin{array}{l}\text { Positive effect on individuals' } \\
\text { happiness over time in Germany }\end{array}$ \\
\hline Becchetti et al. (2008) & $\begin{array}{l}\text { - attending social gatherings } \\
\text { - attending cultural events } \\
\text { - performing volunteer work } \\
\text { - participating in sports } \\
\text { - attending religious events } \\
\end{array}$ & $\begin{array}{l}\text { Positive association with individuals' } \\
\text { life satisfaction over time in Germany }\end{array}$ \\
\hline \multirow[t]{2}{*}{ Bruni and Stanca, (2008) } & $\begin{array}{l}\text { - volunteering in union organisations } \\
\text { - volunteering in political organisations } \\
\text { - volunteering in professional organisations } \\
\text { - volunteering in environment organisations } \\
\end{array}$ & $\begin{array}{l}\text { Non-significant association with cross- } \\
\text { national individuals' life satisfaction }\end{array}$ \\
\hline & $\begin{array}{l}\text { - volunteering in church organisations } \\
\text { - volunteering in sport organisations } \\
\text { - volunteering in art organisations } \\
\text { - volunteering in charity organisations }\end{array}$ & $\begin{array}{c}\text { Positive association with cross- } \\
\text { national individuals' life satisfaction }\end{array}$ \\
\hline Guiso et al. (2003) & $\begin{array}{l}\text { - raised religiously at home } \\
\text { - attending religious services } \\
\text { - believing in God }\end{array}$ & $\begin{array}{l}\text { Positive association with cross- } \\
\text { national individuals' trust }\end{array}$ \\
\hline
\end{tabular}


Table 2: Factor Analysis - Bonding and Bridging (Step 3)

\begin{tabular}{lccccc}
\hline \hline Factor & Eigenvalue & Difference & Proportion & Cumulative & \\
\cline { 2 - 5 } Factor1 & 0.87608 & 0.61096 & 1.3965 & 1.3965 & 1.8192 \\
Factor2 & 0.26512 & 0.14275 & 0.4226 & 2.0142 & \\
Factor3 & 0.12237 & 0.11105 & 0.1951 & 2.0323 & \\
Factor4 & 0.01132 & 0.05488 & 0.018 & 1.9628 & \\
Factor5 & -0.04355 & 0.08164 & -0.0694 & 1.7633 & \\
Factor6 & -0.1252 & 0.01579 & -0.1996 & 1.5385 & \\
Factor7 & -0.14099 & 0.01337 & -0.2247 & 1.2925 & \\
Factor8 & -0.15435 & 0.02913 & -0.2461 & & \\
Factor9 & -0.18348 & & -0.2925 & & \\
& & & & & \\
Variable & Factor1 & Factor2 & Factor3 & Factor4 & Uniqueness \\
\cline { 2 - 4 } importance of family & 0.2327 & 0.2274 & -0.0894 & 0.0413 & 0.8844 \\
importance of religion & 0.483 & 0.136 & 0.0282 & -0.013 & 0.7473 \\
importance of work & 0.3344 & 0.2072 & -0.1157 & 0.0114 & 0.8317 \\
child obedience & 0.3375 & -0.1833 & 0.0527 & 0.0459 & 0.8476 \\
trust in institutions & 0.2145 & 0.1159 & 0.2269 & -0.0076 & 0.889 \\
importance of child independence & -0.2882 & 0.2334 & -0.0378 & -0.0441 & 0.8591 \\
importance of child imagination & -0.235 & 0.1675 & 0.0311 & 0.0189 & 0.9154 \\
justified homosexuality & -0.3776 & 0.0456 & -0.0389 & 0.0653 & 0.8496 \\
trust in people & -0.1897 & 0.1427 & 0.2049 & 0.0242 & 0.9011 \\
\hline \hline Observations: & & & & & \\
\end{tabular}

Observations: 251718; Correlation method: Principal factors rotation; Number of parameters: 30 
Table 3: Factor Analysis - Bonding and Bridging (Step 4)

\begin{tabular}{|c|c|c|c|c|c|}
\hline Factor & Eigenvalue & Difference & Proportion & Cumulative & \\
\hline Factor1 & 1.10566 & 0.54352 & 0.965 & 0.965 & \\
\hline Factor2 & 0.56214 & 0.43651 & 0.4906 & 1.4556 & \\
\hline Factor3 & 0.12563 & 0.0482 & 0.1096 & 1.5652 & \\
\hline Factor4 & 0.07743 & 0.12878 & 0.0676 & 1.6328 & \\
\hline Factor5 & -0.05135 & 0.03205 & -0.0448 & 1.588 & \\
\hline Factor6 & -0.0834 & 0.00515 & -0.0728 & 1.5152 & \\
\hline Factor7 & -0.08855 & 0.14675 & -0.0773 & 1.4379 & \\
\hline Factor8 & -0.2353 & 0.03116 & -0.2054 & 1.2326 & \\
\hline Factor9 & -0.26646 & . & -0.2326 & 1 & \\
\hline Variable & Factor1 & Factor2 & Factor3 & Factor4 & Uniqueness \\
\hline Importance of family > importance of friends (a) & -0.245 & 0.2356 & 0.2034 & 0.0231 & 0.8426 \\
\hline Importance of family < importance of friends (a) & 0.1951 & -0.13 & -0.2386 & -0.0161 & 0.8879 \\
\hline Importance of work > importance of leisure (b) & -0.3329 & 0.4101 & -0.1049 & 0.0433 & 0.7082 \\
\hline Importance of work < importance of leisure (b) & 0.3181 & -0.3733 & 0.1216 & -0.0285 & 0.7438 \\
\hline Importance of religion > importance of politics (c) & -0.5551 & -0.2788 & -0.0124 & 0.0759 & 0.6083 \\
\hline Importance of religion < importance of politics (c) & 0.5239 & 0.3167 & 0.0197 & -0.0746 & 0.6192 \\
\hline Child independence Vs. Child obedience & 0.2769 & 0.0645 & 0.0005 & 0.1329 & 0.9015 \\
\hline Trust in people Vs. trust in institutions & 0.2087 & 0.0065 & -0.0153 & 0.1526 & 0.9329 \\
\hline Justified homosexuality & 0.3046 & -0.0051 & 0.0283 & 0.1471 & 0.8848 \\
\hline
\end{tabular}

Observations: 256629; Correlation method: Principal factors rotation; Number of parameters: 30

(a) Base category: Importance of family = importance of friends

(b) Base category: Importance of work = importance of leisure

(c) Base category: Importance of religion = importance of politics 
Table 4: Life Satisfaction Equation - Pooled World Sample

\begin{tabular}{|c|c|c|}
\hline & & lifesat \\
\hline \multirow[t]{5}{*}{ Bonding } & Importance of family & $\begin{array}{c}0.256 \\
(13.87)^{\star *}\end{array}$ \\
\hline & Importance of religion & $\begin{array}{c}0.229 \\
(16.75)^{\star *}\end{array}$ \\
\hline & Importance of work & $\begin{array}{c}0.04 \\
(3.68)^{\star *}\end{array}$ \\
\hline & Important child qualities: obedience & $\begin{array}{c}0.071 \\
(5.73)^{\star *}\end{array}$ \\
\hline & Trust in institutions & $\begin{array}{c}0.215 \\
(16.09)^{\star *}\end{array}$ \\
\hline \multirow[t]{4}{*}{ Bridging } & Important child qualities: independence & $\begin{array}{c}-0.005 \\
-0.46\end{array}$ \\
\hline & Important child qualities: imagination & $\begin{array}{c}-0.02 \\
-1.7\end{array}$ \\
\hline & Trust in people & $\begin{array}{c}0.206 \\
(14.48)^{\star *}\end{array}$ \\
\hline & Justified homosexuality & $\begin{array}{c}-0.106 \\
(7.57)^{\star \star}\end{array}$ \\
\hline \multirow[t]{18}{*}{ Controls } & female & $\begin{array}{c}0.057 \\
(5.65)^{\star *}\end{array}$ \\
\hline & age & $\begin{array}{c}-0.041 \\
(18.42)^{\star *}\end{array}$ \\
\hline & age2 & $\begin{array}{c}0 \\
(20.55)^{\star *}\end{array}$ \\
\hline & lower education & $\begin{array}{c}-0.088 \\
(4.01)^{\star *}\end{array}$ \\
\hline & upper education & $\begin{array}{c}0.098 \\
(6.50)^{\star *}\end{array}$ \\
\hline & married & $\begin{array}{c}0.307 \\
(24.18)^{\star *}\end{array}$ \\
\hline & no children & $\begin{array}{c}0.112 \\
(8.03)^{\star *}\end{array}$ \\
\hline & children three or more & $\begin{array}{c}0.032 \\
(2.33)^{*}\end{array}$ \\
\hline & good health & $\begin{array}{c}0.591 \\
(36.57)^{\star *}\end{array}$ \\
\hline & bad health & $\begin{array}{c}-0.77 \\
(31.29)^{\star *}\end{array}$ \\
\hline & breadwinner & $\begin{array}{c}-0.021 \\
-1.78\end{array}$ \\
\hline & employment status - part-time & $\begin{array}{l}-0.045 \\
(2.13)^{*}\end{array}$ \\
\hline & employment status - self-employed & $\begin{array}{c}0.03 \\
-1.56\end{array}$ \\
\hline & employment status - unemployed & $\begin{array}{c}-0.413 \\
(16.13)^{\star *}\end{array}$ \\
\hline & economically inactive & $\begin{array}{c}0.029 \\
(2.22)^{\star}\end{array}$ \\
\hline & low income group & $\begin{array}{c}-0.368 \\
(20.32)^{\star *}\end{array}$ \\
\hline & high income group & $\begin{array}{c}0.293 \\
(9.68)^{\star *}\end{array}$ \\
\hline & Observations & 240811 \\
\hline
\end{tabular}

Robust z-statistics in parentheses. ${ }^{*}$ significant at $5 \%$ level; ${ }^{* *}$ significant at $1 \%$ level Countries and years dummies omitted. 
Table 5: Life Satisfaction Equations - Pooled World Sample and World Regions

\begin{tabular}{|c|c|c|c|c|c|c|c|c|c|}
\hline & World & $\begin{array}{c}1 \\
\text { North } \\
\text { America } \\
\end{array}$ & $\begin{array}{c}2 \\
\text { Central } \\
\text { America } \\
\end{array}$ & $\begin{array}{c}3 \\
\text { South } \\
\text { America } \\
\end{array}$ & $\begin{array}{c}4 \\
\text { North } \\
\text { Europe }\end{array}$ & $\begin{array}{c}5 \\
\text { Central } \\
\text { Europe } \\
\end{array}$ & $\begin{array}{c}6 \\
\text { South } \\
\text { Europe }\end{array}$ & $\begin{array}{c}7 \\
\text { Balcans } \\
\end{array}$ & \begin{tabular}{l}
\multicolumn{1}{c}{8} \\
Central- \\
Eastern \\
Europe \\
\end{tabular} \\
\hline Importance of family > importance of friends (a) & $\begin{array}{c}-0.138 \\
(13.35)^{\star \star}\end{array}$ & $\begin{array}{l}-0.293 \\
(8.22)^{* *}\end{array}$ & $\begin{array}{l}-0.157 \\
(2.48)^{\star}\end{array}$ & $\begin{array}{c}-0.163 \\
(5.43)^{\star \star}\end{array}$ & $\begin{array}{l}-0.232 \\
(9.63)^{\star \star}\end{array}$ & $\begin{array}{l}-0.183 \\
(6.35)^{\star \star}\end{array}$ & $\begin{array}{l}-0.142 \\
(4.97)^{\star \star}\end{array}$ & $\begin{array}{l}-0.157 \\
(4.09)^{* *}\end{array}$ & $\begin{array}{l}-0.137 \\
(4.85)^{\star \star}\end{array}$ \\
\hline Importance of family < importance of friends (a) & $\begin{array}{c}-0.283 \\
(13.26)^{\star \star}\end{array}$ & $\begin{array}{l}-0.496 \\
(3.25)^{\star *}\end{array}$ & $\begin{array}{l}-0.266 \\
(2.04)^{*}\end{array}$ & $\begin{array}{c}-0.206 \\
(3.39)^{\star \star}\end{array}$ & $\begin{array}{l}-0.343 \\
(7.02)^{\star \star}\end{array}$ & $\begin{array}{l}-0.421 \\
(5.46)^{\star \star}\end{array}$ & $\begin{array}{l}-0.346 \\
(4.62)^{\star \star}\end{array}$ & $\begin{array}{l}-0.615 \\
(3.28)^{\star \star}\end{array}$ & $\begin{array}{l}-0.224 \\
(3.62)^{\star \star}\end{array}$ \\
\hline Importance of work > importance of leisure (b) & $\begin{array}{c}-0.1 \\
(8.97)^{\star *}\end{array}$ & $\begin{array}{l}-0.084 \\
-1.25\end{array}$ & $\begin{array}{l}-0.102 \\
(2.04)^{\star}\end{array}$ & $\begin{array}{c}-0.133 \\
(5.25)^{\star \star}\end{array}$ & $\begin{array}{l}-0.093 \\
(3.02)^{\star \star}\end{array}$ & $\begin{array}{c}-0.134 \\
(4.02)^{\star \star}\end{array}$ & $\begin{array}{l}-0.107 \\
(2.76)^{* *}\end{array}$ & $\begin{array}{l}-0.05 \\
-0.69\end{array}$ & $\begin{array}{c}-0.038 \\
-1.2\end{array}$ \\
\hline Importance of work < importance of leisure (b) & $\begin{array}{l}-0.07 \\
(5.50)^{\star \star}\end{array}$ & $\begin{array}{l}-0.046 \\
-1.19\end{array}$ & $\begin{array}{l}-0.251 \\
(2.88)^{\star \star}\end{array}$ & $\begin{array}{l}-0.109 \\
(3.12)^{\star \star}\end{array}$ & $\begin{array}{l}-0.109 \\
(3.30)^{\star \star}\end{array}$ & $\begin{array}{l}-0.194 \\
(4.40)^{* \star}\end{array}$ & $\begin{array}{l}-0.116 \\
(2.60)^{\star \star}\end{array}$ & $\begin{array}{l}-0.019 \\
-0.27\end{array}$ & $\begin{array}{l}-0.047 \\
-1.44\end{array}$ \\
\hline Importance of religion > importance of politics (c) & $\begin{array}{c}0.114 \\
(10.51)^{\star *}\end{array}$ & $\begin{array}{c}0.09 \\
(2.21)^{\star}\end{array}$ & $\begin{array}{c}0.119 \\
(2.46)^{*}\end{array}$ & $\begin{array}{c}0.144 \\
(4.80)^{\star \star}\end{array}$ & $\begin{array}{c}0.197 \\
(4.78)^{\star \star}\end{array}$ & $\begin{array}{c}0.134 \\
(3.31)^{* \star}\end{array}$ & $\begin{array}{c}0.167 \\
(5.75)^{\star *}\end{array}$ & $\begin{array}{c}0.161 \\
(5.24)^{\star *}\end{array}$ & $\begin{array}{c}0.089 \\
(2.77)^{\star \star}\end{array}$ \\
\hline Importance of religion < importance of politics (c) & $\begin{array}{l}-0.027 \\
(1.97)^{\star}\end{array}$ & $\begin{array}{l}-0.074 \\
-1.89\end{array}$ & $\begin{array}{l}-0.096 \\
-1.05\end{array}$ & $\begin{array}{l}-0.112 \\
(3.17)^{\star \star}\end{array}$ & $\begin{array}{l}-0.001 \\
-0.04\end{array}$ & $\begin{array}{l}0.008 \\
-0.17\end{array}$ & $\begin{array}{l}-0.005 \\
-0.12\end{array}$ & $\begin{array}{c}0.187 \\
(3.12)^{\star *}\end{array}$ & $\begin{array}{l}-0.035 \\
-1.08\end{array}$ \\
\hline Child independence Vs. Child obedience & $\begin{array}{c}-0.06 \\
(5.44)^{\star \star}\end{array}$ & $\begin{array}{c}-0.109 \\
(2.93)^{* \star}\end{array}$ & $\begin{array}{l}-0.113 \\
(2.67)^{\star \star}\end{array}$ & $\begin{array}{l}-0.179 \\
(4.94)^{\star \star}\end{array}$ & $\begin{array}{l}-0.057 \\
(2.32)^{*}\end{array}$ & $\begin{array}{l}-0.051 \\
-1.31\end{array}$ & $\begin{array}{c}-0.09 \\
(2.75)^{\star *}\end{array}$ & $\begin{array}{l}0.06 \\
-0.98\end{array}$ & $\begin{array}{l}0.021 \\
-0.76\end{array}$ \\
\hline Trust in people Vs. trust in institutions & $\begin{array}{c}0.07 \\
(4.99)^{\star *}\end{array}$ & $\begin{array}{l}0.027 \\
-0.47\end{array}$ & $\begin{array}{l}-0.002 \\
-0.03\end{array}$ & $\begin{array}{l}-0.038 \\
-0.77\end{array}$ & $\begin{array}{l}-0.01 \\
-0.44\end{array}$ & $\begin{array}{c}0.198 \\
(4.52)^{\star *}\end{array}$ & $\begin{array}{c}0.138 \\
(3.06)^{\star *}\end{array}$ & $\begin{array}{l}0.012 \\
-0.19\end{array}$ & $\begin{array}{c}0.229 \\
(6.14)^{\star \star}\end{array}$ \\
\hline Justified homosexuality & $\begin{array}{l}-0.127 \\
(8.93)^{\star \star}\end{array}$ & $\begin{array}{l}-0.171 \\
(4.17)^{\star *}\end{array}$ & $\begin{array}{l}-0.221 \\
(5.62)^{\star *}\end{array}$ & $\begin{array}{c}-0.25 \\
(7.44)^{\star \star}\end{array}$ & $\begin{array}{l}-0.285 \\
(8.79)^{\star \star}\end{array}$ & $\begin{array}{l}-0.105 \\
-1.8\end{array}$ & $\begin{array}{l}-0.208 \\
(4.92)^{\star *}\end{array}$ & $\begin{array}{l}-0.132 \\
(2.93)^{\star *}\end{array}$ & $\begin{array}{l}-0.035 \\
-1.34\end{array}$ \\
\hline female & $\begin{array}{c}0.069 \\
(6.70)^{\star \star}\end{array}$ & $\begin{array}{c}0.126 \\
(2.71)^{\star \star}\end{array}$ & $\begin{array}{c}0.104 \\
(2.04)^{*}\end{array}$ & $\begin{array}{l}-0.037 \\
-1.63\end{array}$ & $\begin{array}{c}0.164 \\
(5.40)^{\star \star}\end{array}$ & $\begin{array}{c}0.03 \\
-0.83\end{array}$ & $\begin{array}{c}0 \\
-0.01\end{array}$ & $\begin{array}{c}0.139 \\
(2.79)^{\star * *}\end{array}$ & $\begin{array}{c}0.098 \\
(3.93)^{\star *}\end{array}$ \\
\hline age & $\begin{array}{c}-0.041 \\
(17.95)^{\star \star}\end{array}$ & $\begin{array}{c}-0.03 \\
(4.15)^{* *}\end{array}$ & $\begin{array}{l}-0.051 \\
(4.58)^{\star \star}\end{array}$ & $\begin{array}{l}-0.016 \\
(2.56)^{\star}\end{array}$ & $\begin{array}{l}-0.053 \\
(8.80)^{\star \star}\end{array}$ & $\begin{array}{l}-0.036 \\
(5.31)^{* \star}\end{array}$ & $\begin{array}{l}-0.045 \\
(7.36)^{\star \star}\end{array}$ & $\begin{array}{l}-0.063 \\
(6.05)^{* *}\end{array}$ & $\begin{array}{c}-0.059 \\
(12.52)^{\star *}\end{array}$ \\
\hline age2 & $\begin{array}{c}0 \\
(20.46)^{* *}\end{array}$ & $\begin{array}{c}0 \\
(5.74)^{\star \star}\end{array}$ & $\begin{array}{c}0.001 \\
(5.30)^{\star \star}\end{array}$ & $\begin{array}{c}0 \\
(3.51)^{\star \star}\end{array}$ & $\begin{array}{c}0.001 \\
(9.32)^{\star \star}\end{array}$ & $\begin{array}{c}0 \\
(6.23)^{\star \star}\end{array}$ & $\begin{array}{c}0 \\
(6.71)^{\star \star}\end{array}$ & $\begin{array}{c}0.001 \\
(6.16)^{\star \star}\end{array}$ & $\begin{array}{c}0.001 \\
(11.46)^{\star \star}\end{array}$ \\
\hline lower education & $\begin{array}{c}-0.09 \\
(4.26)^{\star \star}\end{array}$ & $\begin{array}{l}0.114 \\
-1.29\end{array}$ & $\begin{array}{l}0.112 \\
-1.87\end{array}$ & $\begin{array}{c}0.105 \\
(2.28)^{*}\end{array}$ & $\begin{array}{l}-0.073 \\
(2.02)^{\star}\end{array}$ & $\begin{array}{l}-0.227 \\
(4.42)^{* *}\end{array}$ & $\begin{array}{l}-0.184 \\
(3.70)^{\star *}\end{array}$ & $\begin{array}{c}-0.22 \\
(3.74)^{\star \star}\end{array}$ & $\begin{array}{c}-0.24 \\
(5.11)^{\star \star}\end{array}$ \\
\hline upper education & $\begin{array}{c}0.103 \\
(7.06)^{\star \star}\end{array}$ & $\begin{array}{l}0.051 \\
-0.78\end{array}$ & $\begin{array}{l}-0.071 \\
(2.12)^{*}\end{array}$ & $\begin{array}{l}0.065 \\
-1.59\end{array}$ & $\begin{array}{c}0.025 \\
-0.8\end{array}$ & $\begin{array}{l}0.075 \\
-1.53\end{array}$ & $\begin{array}{c}0.131 \\
(2.76)^{\star \star}\end{array}$ & $\begin{array}{c}0.128 \\
(3.45)^{\star *}\end{array}$ & $\begin{array}{c}0.32 \\
(9.49)^{\star \star}\end{array}$ \\
\hline married & $\begin{array}{c}0.333 \\
(25.54)^{\star \star}\end{array}$ & $\begin{array}{c}0.6 \\
(12.53)^{\star \star}\end{array}$ & $\begin{array}{c}0.297 \\
(11.28)^{* \star}\end{array}$ & $\begin{array}{c}0.274 \\
(9.11)^{\star \star}\end{array}$ & $\begin{array}{c}0.555 \\
(19.37)^{\star \star}\end{array}$ & $\begin{array}{c}0.422 \\
(8.96)^{* \star}\end{array}$ & $\begin{array}{c}0.55 \\
(14.35)^{\star *}\end{array}$ & $\begin{array}{c}0.356 \\
(6.79)^{\star *}\end{array}$ & $\begin{array}{c}0.365 \\
(9.57)^{\star \star}\end{array}$ \\
\hline no children & $\begin{array}{c}0.098 \\
(7.12)^{\star \star}\end{array}$ & $\begin{array}{c}0.159 \\
(2.83)^{\star *}\end{array}$ & $\begin{array}{l}0.076 \\
-1.43\end{array}$ & $\begin{array}{c}0.162 \\
(4.07)^{\star \star}\end{array}$ & $\begin{array}{l}-0.001 \\
-0.03\end{array}$ & $\begin{array}{l}0.087 \\
(2.36)^{\star}\end{array}$ & $\begin{array}{c}0.096 \\
(2.65)^{\star *}\end{array}$ & $\begin{array}{c}0.113 \\
(2.20)^{\star}\end{array}$ & $\begin{array}{c}0.161 \\
(3.59)^{\star \star}\end{array}$ \\
\hline children three or more & $\begin{array}{c}0.048 \\
(3.57)^{\star \star}\end{array}$ & $\begin{array}{c}0.184 \\
(5.16)^{* *}\end{array}$ & $\begin{array}{l}0.011 \\
-0.19\end{array}$ & $\begin{array}{l}0.032 \\
-1.02\end{array}$ & $\begin{array}{l}0.058 \\
-1.94\end{array}$ & $\begin{array}{l}0.012 \\
-0.23\end{array}$ & $\begin{array}{c}-0.024 \\
-0.79\end{array}$ & $\begin{array}{l}-0.007 \\
-0.11\end{array}$ & $\begin{array}{l}0.031 \\
-1.07\end{array}$ \\
\hline good health & $\begin{array}{c}0.604 \\
(36.87)^{\star *}\end{array}$ & $\begin{array}{c}0.921 \\
(18.87)^{\star \star}\end{array}$ & $\begin{array}{c}0.656 \\
(24.06)^{* *}\end{array}$ & $\begin{array}{c}0.476 \\
(12.45)^{\star *}\end{array}$ & $\begin{array}{c}0.897 \\
(22.42)^{\star *}\end{array}$ & $\begin{array}{c}0.833 \\
(14.12)^{\star \star}\end{array}$ & $\begin{array}{c}0.638 \\
(13.98)^{* *}\end{array}$ & $\begin{array}{c}0.711 \\
(12.58)^{\star \star}\end{array}$ & $\begin{array}{c}0.551 \\
(18.27)^{\star *}\end{array}$ \\
\hline bad health & $\begin{array}{c}-0.772 \\
(31.64)^{\star *}\end{array}$ & $\begin{array}{c}-0.84 \\
(6.32)^{* \star}\end{array}$ & $\begin{array}{l}-0.497 \\
(5.10)^{\star \star}\end{array}$ & $\begin{array}{l}-0.693 \\
(9.51)^{\star \star}\end{array}$ & $\begin{array}{c}-0.999 \\
(11.73)^{\star \star}\end{array}$ & $\begin{array}{c}-0.991 \\
(17.91)^{\star *}\end{array}$ & $\begin{array}{c}-0.95 \\
(9.38)^{* *}\end{array}$ & $\begin{array}{l}-0.714 \\
(9.24)^{\star *}\end{array}$ & $\begin{array}{c}-0.668 \\
(14.83)^{* *}\end{array}$ \\
\hline breadwinner & $\begin{array}{l}-0.019 \\
-1.64\end{array}$ & $\begin{array}{l}0.024 \\
-0.57\end{array}$ & $\begin{array}{l}0.022 \\
-0.52\end{array}$ & $\begin{array}{l}-0.02 \\
-0.61\end{array}$ & $\begin{array}{l}-0.035 \\
-1.02\end{array}$ & $\begin{array}{l}-0.108 \\
(2.13)^{*}\end{array}$ & $\begin{array}{l}0.046 \\
-1.29\end{array}$ & $\begin{array}{l}0.011 \\
-0.22\end{array}$ & $\begin{array}{l}-0.007 \\
-0.22\end{array}$ \\
\hline employment status - part-time employee (d) & $\begin{array}{l}-0.044 \\
(2.08)^{*}\end{array}$ & $\begin{array}{l}0.039 \\
-0.71\end{array}$ & $\begin{array}{l}-0.142 \\
(2.07)^{\star}\end{array}$ & $\begin{array}{l}0.047 \\
-1.28\end{array}$ & $\begin{array}{l}-0.065 \\
(2.09)^{*}\end{array}$ & $\begin{array}{l}-0.04 \\
-0.6\end{array}$ & $\begin{array}{l}-0.168 \\
(2.29)^{*}\end{array}$ & $\begin{array}{l}-0.092 \\
-0.66\end{array}$ & $\begin{array}{l}0.088 \\
-1.21\end{array}$ \\
\hline employment status - self-employed (d) & $\begin{array}{l}0.026 \\
-1.37\end{array}$ & $\begin{array}{l}0.063 \\
-0.85\end{array}$ & $\begin{array}{l}-0.018 \\
-0.26\end{array}$ & $\begin{array}{l}-0.021 \\
-0.38\end{array}$ & $\begin{array}{l}0.021 \\
-0.37\end{array}$ & $\begin{array}{l}-0.05 \\
-0.73\end{array}$ & $\begin{array}{c}0.143 \\
(2.45)^{\star}\end{array}$ & $\begin{array}{c}0.153 \\
(2.03)^{\star}\end{array}$ & $\begin{array}{l}0.074 \\
-1.02\end{array}$ \\
\hline employment status - unemployed (d) & $\begin{array}{c}-0.412 \\
(16.50)^{\star *}\end{array}$ & $\begin{array}{c}-0.34 \\
(2.50)^{\star}\end{array}$ & $\begin{array}{l}-0.146 \\
-1.49\end{array}$ & $\begin{array}{l}-0.319 \\
(6.29)^{\star \star}\end{array}$ & $\begin{array}{c}-0.766 \\
(12.68)^{* \star}\end{array}$ & $\begin{array}{c}-1.13 \\
(11.61)^{\star *}\end{array}$ & $\begin{array}{l}-0.639 \\
(9.67)^{\star \star}\end{array}$ & $\begin{array}{l}-0.259 \\
(4.13)^{\star *}\end{array}$ & $\begin{array}{c}-0.638 \\
(11.65)^{\star *}\end{array}$ \\
\hline economically inactive & $\begin{array}{c}0.033 \\
(2.61)^{\star *}\end{array}$ & $\begin{array}{c}0.195 \\
(3.72)^{\star *}\end{array}$ & $\begin{array}{l}0.013 \\
-0.21\end{array}$ & $\begin{array}{l}0.018 \\
-0.36\end{array}$ & $\begin{array}{l}-0.022 \\
-0.44\end{array}$ & $\begin{array}{l}0.097 \\
(2.09)^{*}\end{array}$ & $\begin{array}{l}-0.018 \\
-0.44\end{array}$ & $\begin{array}{l}0.064 \\
-1.47\end{array}$ & $\begin{array}{l}0.062 \\
-1.82\end{array}$ \\
\hline low income group & $\begin{array}{c}-0.365 \\
(20.29)^{\star \star}\end{array}$ & $\begin{array}{l}-0.254 \\
(3.52)^{\star *}\end{array}$ & $\begin{array}{c}-0.188 \\
(3.35)^{\star *}\end{array}$ & $\begin{array}{l}-0.212 \\
(5.48)^{\star \star}\end{array}$ & $\begin{array}{l}-0.234 \\
(6.25)^{\star \star}\end{array}$ & $\begin{array}{c}-0.24 \\
(5.10)^{\star \star}\end{array}$ & $\begin{array}{l}-0.178 \\
(3.70)^{\star \star}\end{array}$ & $\begin{array}{l}-0.574 \\
(7.09)^{\star *}\end{array}$ & $\begin{array}{l}-0.402 \\
(9.16)^{\star \star}\end{array}$ \\
\hline high income group & $\begin{array}{c}0.296 \\
(9.96)^{\star \star}\end{array}$ & $\begin{array}{c}0.259 \\
(3.60)^{\star *}\end{array}$ & $\begin{array}{l}0.215 \\
(2.10)^{\star}\end{array}$ & $\begin{array}{c}0.243 \\
(5.22)^{* *}\end{array}$ & $\begin{array}{c}0.129 \\
(4.33)^{\star \star}\end{array}$ & $\begin{array}{l}0.08 \\
-1.67\end{array}$ & $\begin{array}{l}0.089 \\
-1.79\end{array}$ & $\begin{array}{c}0.543 \\
(5.81)^{\star \star}\end{array}$ & $\begin{array}{c}0.391 \\
(8.16)^{\star \star}\end{array}$ \\
\hline $\begin{array}{l}\text { (b) Base category: Importance of work = import } \\
\text { (c) Base category: Importance of religion = imp } \\
\text { (d) Base category: employment status - full-tim }\end{array}$ & $\frac{240811}{\% \text { level; }{ }^{* \star}}$ & $\frac{10443}{1 \text { gnificant }}$ & $\frac{11039}{1 \% \text { leve }}$ & 23527 & $\frac{21678}{1 \text { d years }}$ & $\frac{17101}{\text { mmies or }}$ & $\frac{21177}{\text { ted. }}$ & 10561 & 24749 \\
\hline
\end{tabular}




\begin{tabular}{|c|c|c|c|c|c|c|c|c|}
\hline & 9 & 10 & 11 & 12 & 13 & 14 & 15 & 16 \\
\hline & Baltics & $\begin{array}{l}\text { Common } \\
\text { wealth of } \\
\text { Independe } \\
\text { nt States } \\
\text { (FSU 12) }\end{array}$ & $\begin{array}{l}\text { North- } \\
\text { Africa and } \\
\text { Middle- } \\
\text { East }\end{array}$ & $\begin{array}{c}\text { Sub- } \\
\text { Saharian } \\
\text { Africa }\end{array}$ & East Asia & $\begin{array}{c}\text { South } \\
\text { Asia }\end{array}$ & $\begin{array}{l}\text { China and } \\
\text { Vietnam }\end{array}$ & Oceania \\
\hline \multirow[t]{2}{*}{ Importance of family > importance of friends (a) } & 0.072 & -0.106 & -0.023 & -0.101 & -0.113 & -0.135 & -0.009 & -0.338 \\
\hline & -1.49 & $(3.48)^{\star \star}$ & -0.4 & $(3.10)^{\star \star}$ & $(2.33)^{\star}$ & $(2.27)^{\star}$ & -0.17 & $(6.42)^{\star \star}$ \\
\hline \multirow[t]{2}{*}{ Importance of family < importance of friends (a) } & -0.076 & -0.246 & -0.264 & -0.168 & -0.574 & -0.234 & -0.349 & -0.577 \\
\hline & -0.95 & $(4.03)^{\star \star}$ & $(2.07)^{\star}$ & -1.53 & $(5.23)^{\star \star}$ & $(2.11)^{\star}$ & $(2.38)^{\star}$ & $(3.60)^{\star \star}$ \\
\hline \multirow[t]{2}{*}{ Importance of work > importance of leisure (b) } & -0.112 & 0.009 & -0.098 & -0.131 & -0.06 & -0.119 & 0.016 & -0.126 \\
\hline & $(3.40)^{\star \star}$ & -0.19 & $(2.82)^{\star \star}$ & $(2.90)^{\star \star}$ & -0.92 & -1.56 & -0.29 & -1.23 \\
\hline \multirow[t]{2}{*}{ Importance of work < importance of leisure (b) } & -0.129 & -0.004 & -0.072 & -0.056 & 0.051 & -0.054 & 0.061 & -0.255 \\
\hline & -1.39 & -0.09 & -1.21 & -0.7 & -1.17 & -0.43 & -0.55 & $(4.26)^{\star \star}$ \\
\hline \multirow[t]{2}{*}{ Importance of religion > importance of politics (c) } & 0.08 & 0.061 & 0.152 & 0.037 & 0.259 & -0.035 & 0.015 & 0.064 \\
\hline & -1.49 & -1.69 & $(3.11)^{\star \star}$ & -0.98 & $(4.67)^{\star \star}$ & -0.62 & -0.18 & -0.77 \\
\hline \multirow[t]{2}{*}{ Importance of religion < importance of politics (c) } & 0.018 & -0.026 & -0.022 & -0.249 & 0.03 & -0.27 & 0.229 & -0.074 \\
\hline & -0.41 & -0.72 & -0.26 & $(3.47)^{\star \star}$ & -0.5 & -1.66 & $(3.51)^{\star \star}$ & -0.86 \\
\hline \multirow[t]{2}{*}{ Child independence Vs. Child obedience } & -0.103 & 0.011 & -0.101 & -0.144 & -0.021 & -0.138 & 0.04 & -0.038 \\
\hline & $(2.58)^{\star \star}$ & -0.23 & $(2.89)^{\star \star}$ & $(2.71)^{\star \star}$ & -0.36 & $(2.01)^{\star}$ & -0.46 & -0.73 \\
\hline \multirow[t]{2}{*}{ Trust in people Vs. trust in institutions } & 0.234 & 0.102 & -0.105 & 0 & 0.115 & 0.068 & -0.024 & 0.123 \\
\hline & $(3.94)^{\star \star}$ & $(2.11)^{*}$ & $(1.98)^{\star}$ & 0 & -1.13 & -0.8 & -0.27 & $(2.34)^{\star}$ \\
\hline \multirow[t]{2}{*}{ Justified homosexuality } & -0.031 & 0.092 & -0.161 & -0.017 & -0.301 & -0.05 & -0.181 & -0.285 \\
\hline & -0.5 & $(2.30)^{*}$ & $(1.96)^{*}$ & -0.31 & $(4.11)^{\star \star}$ & -0.64 & $(2.38)^{*}$ & $(4.30)^{\star \star}$ \\
\hline \multirow[t]{2}{*}{ female } & 0.078 & -0.055 & 0.235 & 0.079 & 0.208 & 0.153 & 0.12 & 0.149 \\
\hline & -1.52 & -1.14 & $(5.83)^{\star \star}$ & $(2.68)^{\star \star}$ & $(3.22)^{\star \star}$ & $(3.87)^{\star \star}$ & $(2.50)^{*}$ & $(2.17)^{\star}$ \\
\hline \multirow[t]{2}{*}{ age } & -0.102 & -0.048 & -0.034 & -0.031 & -0.043 & -0.014 & -0.022 & -0.066 \\
\hline & $(5.94)^{\star \star}$ & $(5.06)^{\star \star}$ & $(3.71)^{\star \star}$ & $(4.88)^{\star \star}$ & $(3.57)^{\star \star}$ & -1.31 & $(2.54)^{\star}$ & $(3.02)^{\star \star}$ \\
\hline \multirow[t]{2}{*}{ age2 } & 0.001 & 0 & 0 & 0 & 0.001 & 0 & 0 & 0.001 \\
\hline & $(6.47)^{\star \star}$ & $(5.18)^{\star \star}$ & $(3.97)^{\star \star}$ & $(7.05)^{\star \star}$ & $(4.09)^{\star \star}$ & $(2.13)^{*}$ & $(3.10)^{\star \star}$ & $(4.24)^{\star \star}$ \\
\hline \multirow[t]{2}{*}{ lower education } & -0.255 & -0.082 & 0.004 & -0.154 & -0.103 & -0.209 & -0.099 & -0.107 \\
\hline & $(3.43)^{\star \star}$ & -1.39 & -0.09 & $(3.34)^{\star \star}$ & -1.01 & $(3.16)^{\star \star \star}$ & -1.33 & -1.62 \\
\hline \multirow[t]{2}{*}{ upper education } & 0.311 & 0.182 & 0.104 & 0.064 & 0.175 & 0.132 & 0.241 & -0.063 \\
\hline & $(3.95)^{\star \star}$ & $(3.83)^{\star \star}$ & -1.81 & -1.31 & $(3.61)^{\star \star}$ & $(2.79)^{\star \star}$ & $(3.71)^{\star \star}$ & -1.11 \\
\hline \multirow[t]{2}{*}{ married } & 0.204 & 0.336 & 0.252 & 0.19 & 0.458 & 0.074 & 0.402 & 0.669 \\
\hline & $(4.57)^{\star \star}$ & $(5.30)^{\star \star}$ & $(3.50)^{\star \star}$ & $(4.29)^{\star \star}$ & $(6.88)^{\star \star}$ & -1.22 & $(4.41)^{\star \star}$ & $(8.30)^{\star \star}$ \\
\hline \multirow[t]{2}{*}{ no children } & 0.001 & 0.218 & 0.025 & 0.15 & 0.029 & 0 & 0.07 & -0.035 \\
\hline & -0.02 & $(2.26)^{*}$ & -0.47 & $(3.01)^{\star \star}$ & -0.37 & -0.01 & -0.88 & -0.45 \\
\hline \multirow[t]{2}{*}{ children three or more } & 0 & 0.157 & -0.013 & -0.05 & -0.018 & 0.003 & 0.152 & 0.146 \\
\hline & -0.01 & $(3.02)^{\star \star}$ & -0.22 & -1.28 & -0.32 & -0.04 & $(2.24)^{\star}$ & $(2.05)^{\star}$ \\
\hline good health & 0.644 & 0.524 & 0.47 & 0.699 & 0.763 & 0.576 & 0.668 & 1.186 \\
\hline & $(11.24)^{\star \star}$ & $(12.58)^{\star \star}$ & $(5.03)^{\star \star}$ & $(11.70)^{* *}$ & $(12.58)^{\star \star}$ & $(7.49)^{\star \star}$ & $(10.81)^{\star \star}$ & $(10.59)^{\star \star}$ \\
\hline bad health & -0.776 & -0.666 & -0.564 & -0.817 & -0.792 & -0.601 & -0.524 & -1.139 \\
\hline & $(10.23)^{\star \star}$ & $(14.27)^{\star \star}$ & $(6.24)^{\star \star}$ & $(11.67)^{* *}$ & $(7.31)^{\star \star}$ & $(5.27)^{\star \star}$ & $(4.96)^{\star \star}$ & $(10.62)^{\star \star *}$ \\
\hline breadwinner & -0.043 & -0.063 & -0.063 & -0.045 & 0.059 & 0.041 & -0.115 & 0.003 \\
\hline & -0.69 & -1.66 & -1.21 & -1.13 & -1.08 & -0.51 & $(2.22)^{\star}$ & -0.02 \\
\hline employment status - part-time employee (d) & 0.149 & 0.012 & -0.101 & -0.192 & -0.124 & -0.194 & -0.013 & -0.118 \\
\hline & $(2.40)^{\star}$ & -0.18 & -1.45 & $(2.42)^{*}$ & -1.59 & -1.91 & -0.11 & -1.16 \\
\hline employment status - self-employed (d) & 0.216 & 0.255 & -0.062 & -0.087 & -0.073 & 0.069 & 0.044 & -0.06 \\
\hline & $(2.83)^{\star \star}$ & $(3.30)^{\star \star}$ & -1.01 & -1.51 & -1.1 & -1.16 & -0.47 & -0.34 \\
\hline employment status - unemployed (d) & -0.639 & -0.272 & -0.393 & -0.367 & -0.433 & -0.092 & -0.629 & -0.406 \\
\hline & $(5.43)^{\star \star \star}$ & $(4.25)^{\star \star}$ & $(4.70)^{\star \star}$ & $(6.38)^{\star \star}$ & $(4.40)^{\star \star}$ & -1.31 & $(2.95)^{\star \star}$ & -1.92 \\
\hline economically inactive & -0.009 & 0.101 & -0.081 & -0.057 & 0.017 & -0.028 & 0.003 & 0.029 \\
\hline & -0.16 & $(2.09)^{*}$ & $(2.03)^{\star}$ & -1.13 & -0.26 & -0.46 & -0.03 & -0.23 \\
\hline low income group & -0.404 & -0.464 & -0.288 & -0.579 & -0.426 & -0.425 & -0.611 & -0.222 \\
\hline & $(5.91)^{\star \star}$ & $(5.75)^{\star \star}$ & $(5.11)^{\star \star}$ & $(9.76)^{\star \star}$ & $(4.55)^{\star \star}$ & $(5.32)^{\star \star}$ & $(6.86)^{\star \star}$ & $(2.61)^{\star \star}$ \\
\hline high income group & 0.395 & 0.454 & 0.214 & 0.609 & 0.629 & 0.647 & 0.624 & 0.244 \\
\hline & $(6.48)^{\star \star}$ & $(7.66)^{\star \star}$ & -1.83 & $(8.11)^{\star \star}$ & $(6.78)^{\star \star}$ & $(7.41)^{\star \star}$ & $(5.93)^{\star \star}$ & $(3.37)^{\star \star}$ \\
\hline Observations & 7417 & 21203 & 13679 & 24543 & 9124 & 13615 & 6908 & 4047 \\
\hline
\end{tabular}


Table 6: Summary of Life Satisfaction Equations - Pooled World Sample and World Regions

\begin{tabular}{|c|c|c|c|c|c|}
\hline & \multirow[t]{2}{*}{ World } & \multicolumn{4}{|c|}{ Regions } \\
\hline & & + sig. & - sig. & non sig. & tot. \\
\hline Importance of family > importance of friends (a) & $\begin{array}{c}-0.138 \\
(13.35)^{\star \star}\end{array}$ & 0 & 13 & 3 & 16 \\
\hline Importance of family < importance of friends (a) & $\begin{array}{c}-0.283 \\
(13.26)^{\star *}\end{array}$ & 0 & 14 & 2 & 16 \\
\hline Importance of work > importance of leisure (b) & $\begin{array}{c}-0.1 \\
(8.97)^{\star *}\end{array}$ & 0 & 8 & 8 & 16 \\
\hline Importance of work < importance of leisure (b) & $\begin{array}{c}-0.07 \\
(5.50)^{\star *}\end{array}$ & 0 & 6 & 10 & 16 \\
\hline Importance of religion > importance of politics (c) & $\begin{array}{c}0.114 \\
(10.51)^{\star *}\end{array}$ & 10 & 0 & 6 & 16 \\
\hline Importance of religion < importance of politics (c) & $\begin{array}{l}-0.027 \\
(1.97)^{*}\end{array}$ & 2 & 2 & 12 & 16 \\
\hline Child independence Vs. Child obedience & $\begin{array}{c}-0.06 \\
(5.44)^{\star *}\end{array}$ & 0 & 9 & 7 & 16 \\
\hline Trust in people Vs. trust in institutions & $\begin{array}{c}0.07 \\
(4.99)^{\star *}\end{array}$ & 7 & 0 & 9 & 16 \\
\hline Justified homosexuality & $\begin{array}{l}-0.127 \\
(8.93)^{\star \star}\end{array}$ & 1 & 10 & 5 & 16 \\
\hline
\end{tabular}


ANNEX

Table 1: Construction of key variables

\begin{tabular}{|c|c|c|c|}
\hline No. & Variable & WVS Code & Construction \\
\hline 1 & Importance of family & A001 & $\begin{array}{l}1 \mathrm{~A} 001=1 \\
0 \mathrm{~A} 001>1 \text { and } \mathrm{A} 001<5\end{array}$ \\
\hline 2 & Importance of friends & A002 & $\begin{array}{l}1 \mathrm{~A} 002=1 \\
0 \mathrm{~A} 002>1 \text { and } \mathrm{A} 002<5\end{array}$ \\
\hline 3 & Importance of leisure & A003 & $\begin{array}{l}1 \mathrm{~A} 003=1 \\
0 \mathrm{~A} 003>1 \text { and } \mathrm{A} 003<5\end{array}$ \\
\hline 4 & Importance of politics & A004 & $\begin{array}{l}1 \mathrm{~A} 004=1 \\
0 \mathrm{~A} 004>1 \text { and } \mathrm{A} 004<5\end{array}$ \\
\hline 5 & Importance of work & A005 & $\begin{array}{l}1 \mathrm{~A} 005=1 \\
0 \mathrm{~A} 005>1 \text { and } \mathrm{A} 005<5\end{array}$ \\
\hline 6 & Importance of religion & A006 & $\begin{array}{l}1 \mathrm{~A} 006=1 \\
0 \mathrm{~A} 006>1 \text { and } \mathrm{A} 006<5\end{array}$ \\
\hline 7 & Important child qualities: independence & A029 & $\begin{array}{l}1 \text { Important } \\
0 \text { Not mentioned }\end{array}$ \\
\hline 8 & Important child qualities: obedience & A042 & $\begin{array}{l}1 \text { Important } \\
0 \text { Not mentioned }\end{array}$ \\
\hline 9 & Important child qualities: imagination & A034 & $\begin{array}{l}1 \text { Important } \\
0 \text { Not mentioned } \\
1 \text { if A001=A002 }\end{array}$ \\
\hline 10 & Importance of family vs. importance of friends & A001, A002 & $\begin{array}{l}2 \text { if } \mathrm{A} 001<\mathrm{A} 002 \\
3 \text { if } \mathrm{A} 001>\mathrm{A} 002 \\
1 \text { if } \mathrm{A} 005=\mathrm{A} 003\end{array}$ \\
\hline 11 & Importance of work vs. importance of leisure & A003, A005 & $\begin{array}{l}2 \text { if } A 005<A 003 \\
3 \text { if } A 005>A 003 \\
1 \text { if } A 006=A 004\end{array}$ \\
\hline 12 & Importance of religion vs. importance of work & A004, A006 & $\begin{array}{l}2 \text { if } \mathrm{A} 006<\mathrm{A} 004 \\
3 \text { if } \mathrm{A} 006>\mathrm{A} 004\end{array}$ \\
\hline 13 & Child independence vs. child obedience & $\mathrm{A} 029, \mathrm{~A} 042$ & $\begin{array}{l}1 \text { if } A 029=1 \text { and } A 042=0 \\
0 \text { Otherwise }\end{array}$ \\
\hline 14 & Trust in people & A165 & $\begin{array}{l}1 \text { Most people can be trusted } \\
0 \text { Can't be too careful (originally=2) }\end{array}$ \\
\hline 15 & Trust in institutions & E069_01-E069_13 & $\begin{array}{l}10<m<=2.5 \\
02.5<m<5 \\
\text { with } m=\text { average E069_01-E069_13 }\end{array}$ \\
\hline 16 & Trust in people vs trust in institutions & A165, E069 & $\begin{array}{l}1 \text { if } \operatorname{Var} 14=1 \& \text { Var } 15=0 \\
0 \text { Otherwise } \\
1 \text { Never justifiable }\end{array}$ \\
\hline 17 & Justifiable: homosexuality & F118 & $\begin{array}{l}2-9 \\
10 \text { Always justifiable }\end{array}$ \\
\hline
\end{tabular}


Table 2: World Regions Classification

\begin{tabular}{|c|c|c|c|c|}
\hline Country code & Country & Region & $\begin{array}{l}\text { Region code } \\
\end{array}$ & OObservations \\
\hline 8 & albania & Balcans & 7 & 1,516 \\
\hline 12 & algeria & N-Afr\&M-East & 11 & 1,124 \\
\hline 20 & andorra & S-Eur & 6 & 973 \\
\hline 32 & argentina & S-Amer & 3 & 2,809 \\
\hline 51 & armenia & CIS & 10 & 1,624 \\
\hline 36 & australia & Oceania & 16 & 3,160 \\
\hline 40 & austria & C-Eur & 5 & 2,498 \\
\hline 31 & azerbaijan & CIS & 10 & 1,682 \\
\hline 50 & bangladesh & S-Asia & 14 & 1,294 \\
\hline 112 & belarus & CIS & 10 & 3,013 \\
\hline 56 & belgium & C-Eur & 5 & 3,876 \\
\hline 70 & bosnia and herzegovina & Balcans & 7 & 2,196 \\
\hline $\begin{array}{c}76 \\
100\end{array}$ & brazil & S-Amer & 3 & 4,178 \\
\hline $\begin{array}{l}100 \\
854\end{array}$ & bulgaria & $\begin{array}{l}\text { CE-Eur } \\
\text { SS Afr }\end{array}$ & 8 & 2,965 \\
\hline $\begin{array}{l}854 \\
124\end{array}$ & $\begin{array}{l}\text { burkina faso } \\
\text { canada }\end{array}$ & $\begin{array}{l}\text { SS-Afr } \\
\text { N-Amer }\end{array}$ & 12 & $\begin{array}{l}1,101 \\
5,226\end{array}$ \\
\hline 152 & chile & S-Amer & 3 & 4,258 \\
\hline 156 & china & China\&Viet & 15 & 2,904 \\
\hline 170 & colombia & S-Amer & 3 & 5,824 \\
\hline 191 & croatia & Balcans & 7 & 989 \\
\hline 196 & cyprus & S-Eur & 6 & 1,014 \\
\hline 203 & czech republic & CE-Eur & 8 & 5,544 \\
\hline 208 & denmark & $\mathrm{N}$-Eur & 4 & 1,838 \\
\hline 214 & dominican republic & C-Amer & 2 & 319 \\
\hline 818 & egypt & N-Afr\&M-East & 11 & 2,858 \\
\hline 222 & el salvador & C-Amer & 2 & 1,085 \\
\hline 233 & estonia & Baltics & 9 & 2,547 \\
\hline 231 & ethiopia & SS-Afr & 12 & 1,250 \\
\hline 246 & finland & N-Eur & 4 & 3,211 \\
\hline 250 & france & S-Eur & 6 & 3,227 \\
\hline 268 & georgia & $\mathrm{CIS}$ & 10 & 1,379 \\
\hline 276 & germany & C-Eur & 5 & 7,641 \\
\hline 288 & ghana & SS-Afr & 12 & 1,438 \\
\hline 826 & great britain & N-Eur & 4 & 2,920 \\
\hline 300 & greece & S-Eur & 6 & 871 \\
\hline 320 & guatemala & C-Amer & 2 & 956 \\
\hline 344 & hong-kong & E-Asia & 13 & 1,110 \\
\hline 348 & hungary & CE-Eur & 8 & 2,360 \\
\hline 352 & iceland & $\begin{array}{l}\text { N-Eur } \\
S \text { SAsia }\end{array}$ & 4 & 1,456 \\
\hline $\begin{array}{l}356 \\
360\end{array}$ & $\begin{array}{l}\text { india } \\
\text { indonesia }\end{array}$ & $\begin{array}{l}\text { S-Asia } \\
\text { S-Asia }\end{array}$ & $\begin{array}{l}14 \\
14\end{array}$ & $\begin{array}{l}6,083 \\
2,453\end{array}$ \\
\hline 364 & iran (islamic republic of) & N-Afr\&M-East & 11 & 3,976 \\
\hline 372 & ireland & N-Eur & 4 & 1,784 \\
\hline 380 & italy & $\mathrm{S}$-Eur & 6 & 4,438 \\
\hline 392 & japan & E-Asia & 13 & 3,010 \\
\hline 400 & jordan & N-Afr\&M-East & 11 & 1,132 \\
\hline 417 & kyrgyzstan & $\mathrm{CIS}$ & 10 & 1,010 \\
\hline 428 & latvia & Baltics & 9 & 2,404 \\
\hline 440 & lithuania & Baltics & 9 & 2,466 \\
\hline 442 & luxembourg & C-Eur & 5 & 1,027 \\
\hline 807 & macedonia, republic of & Balcans & 7 & 1,750 \\
\hline 458 & malaysia & E-Asia & 13 & 1,192 \\
\hline 466 & mali & SS-Afr & 12 & 841 \\
\hline 470 & malta & S-Eur & 6 & 955 \\
\hline 484 & mexico & C-Amer & 2 & 5,988 \\
\hline 528 & netherlands & $\mathrm{N}$-Eur & 4 & 2,721 \\
\hline 554 & new zealand & Oceania & 16 & 887 \\
\hline 566 & nigeria & SS-Afr & 12 & 4,574 \\
\hline 909 & northern ireland & $\mathrm{N}-\mathrm{Eur}$ & 4 & 1,082 \\
\hline 578 & norway & N-Eur & 4 & 3,149 \\
\hline 586 & pakistan & S-Asia & 14 & 1,451 \\
\hline 604 & peru & S-Amer & 3 & 2,456 \\
\hline 608 & philippines & S-Asia & 14 & 2,334 \\
\hline 616 & poland & CE-Eur & 8 & 2,487 \\
\hline $\begin{array}{l}620 \\
630\end{array}$ & $\begin{array}{l}\text { portugal } \\
\text { puerterice }\end{array}$ & S-Eur & 6 & 1,953 \\
\hline $\begin{array}{l}630 \\
410\end{array}$ & $\begin{array}{l}\text { puerto rico } \\
\text { republic of korea }\end{array}$ & $\begin{array}{l}\text { C-Amer } \\
\text { E-Asia }\end{array}$ & $\begin{array}{c}2 \\
13\end{array}$ & $\begin{array}{l}1,725 \\
2,347\end{array}$ \\
\hline 498 & republic of moldova & $\begin{array}{l}\mathrm{CIS} \\
\mathrm{Cld}\end{array}$ & 10 & 2,517 \\
\hline 642 & romania & CE-Eur & 8 & 4,418 \\
\hline 643 & russian federation & CIS & 10 & $\begin{array}{l}4,563 \\
6,563\end{array}$ \\
\hline 646 & rwanda & SS-Afr & 12 & 938 \\
\hline 682 & saudi arabia & N-Afr\&M-East & 11 & 1,303 \\
\hline 911 & serbia & Balcans & 7 & 926 \\
\hline 891 & serbia and montenegro & Balcans & 7 & 3,184 \\
\hline 703 & slovakia & CE-Eur & 8 & 3,435 \\
\hline 705 & slovenia & CE-Eur & 8 & 3,540 \\
\hline 710 & south africa & SS-Afr & 12 & 10,361 \\
\hline 724 & spain & $S$-Eur & 6 & 7,746 \\
\hline 752 & sweden & $\mathrm{N}$-Eur & 4 & 3,517 \\
\hline 756 & switzerland & C-Eur & 5 & 2,059 \\
\hline 158 & taiwan province of china & China\&Viet & 15 & 1,908 \\
\hline 834 & tanzania, united republic of & SS-Afr & 12 & 878 \\
\hline 764 & thailand & E-Asia & 13 & 1,465 \\
\hline 780 & trinidad and tobago & C-Amer & 2 & 966 \\
\hline 792 & turkey & N-Afr\&M-East & 11 & 3,286 \\
\hline 800 & uganda & SS-Afr & 12 & 972 \\
\hline 804 & ukraine & CIS & 10 & 3,415 \\
\hline 840 & united states & N-Amer & 1 & 5,217 \\
\hline 858 & uruguay & S-Amer & 3 & 1,721 \\
\hline 862 & venezuela & S-Amer & 3 & 2,281 \\
\hline 704 & viet nam & China\&Viet & 15 & 2,096 \\
\hline 894 & zambia & SS-Afr & 12 & 1,264 \\
\hline $\begin{array}{l}716 \\
\text { Total }\end{array}$ & zimbabwe & SS-Afr & 12 & $\begin{array}{c}926 \\
240,811\end{array}$ \\
\hline
\end{tabular}

